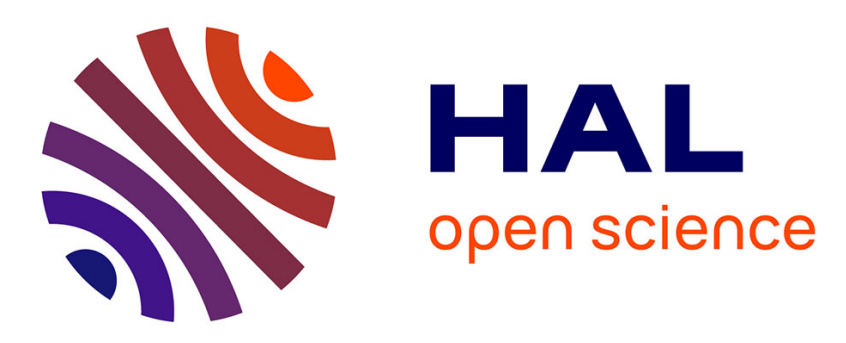

\title{
Fishpond dams affect leaf-litter processing and associated detritivore communities along intermittent low-order streams
}

Brian Four, Marielle Thomas, Evelyne Arce, Aurélie Cebron, Michael Danger, Damien Banas

\section{To cite this version:}

Brian Four, Marielle Thomas, Evelyne Arce, Aurélie Cebron, Michael Danger, et al.. Fishpond dams affect leaf-litter processing and associated detritivore communities along intermittent low-order streams. Freshwater Biology, 2017, 62 (10), pp.1741-1755. 10.1111/fwb.12984 . hal-02317639

\section{HAL Id: hal-02317639 \\ https://hal.science/hal-02317639}

Submitted on 16 Oct 2019

HAL is a multi-disciplinary open access archive for the deposit and dissemination of scientific research documents, whether they are published or not. The documents may come from teaching and research institutions in France or abroad, or from public or private research centers.
L'archive ouverte pluridisciplinaire HAL, est destinée au dépôt et à la diffusion de documents scientifiques de niveau recherche, publiés ou non, émanant des établissements d'enseignement et de recherche français ou étrangers, des laboratoires publics ou privés. 
archives-ouvertes

\section{Fishpond dams affect leaf-litter processing and associated detritivore communities along intermittent low-order streams}

Brian Four, Marielle Thomas, Evelyne Arce, Aurélie Cebron, Michael Danger, Damien Banas

\section{To cite this version:}

Brian Four, Marielle Thomas, Evelyne Arce, Aurélie Cebron, Michael Danger, et al.. Fishpond dams affect leaf-litter processing and associated detritivore communities along intermittent low-order streams. Freshwater Biology, Wiley, 2017, 62 (10), pp.1741-1755. 10.1111/fwb.12984 . hal-02317639

\section{HAL Id: hal-02317639 \\ https://hal.archives-ouvertes.fr/hal-02317639}

Submitted on 16 Oct 2019

HAL is a multi-disciplinary open access archive for the deposit and dissemination of scientific research documents, whether they are published or not. The documents may come from teaching and research institutions in France or abroad, or from public or private research centers.
L'archive ouverte pluridisciplinaire HAL, est destinée au dépôt et à la diffusion de documents scientifiques de niveau recherche, publiés ou non, émanant des établissements d'enseignement et de recherche français ou étrangers, des laboratoires publics ou privés. 


\section{Fishpond dams affect leaf-litter processing and associated detritivore communities along intermittent low-order...}

Article in Freshwater Biology · August 2017

DOI: 10.1111/fwb.12984

CITATIONS

0

6 authors, including:

\section{READS}

8

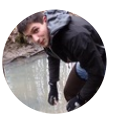

Brian Four

French National Institute for Agricultural Res...

7 PUBLICATIONS 1 CITATION

SEE PROFILE

\section{Aurélie Cébron}

University of Lorraine

64 PUBLICATIONS 1,530 CITATIONS

SEE PROFILE
Evelyne Arce

Pedon Environnement et Milieux Aquatiques 8 PUBLICATIONS 5 CITATIONS

SEE PROFILE

\section{Michael Danger}

University of Lorraine 57 PUBLICATIONS 928 CITATIONS

SEE PROFILE

Some of the authors of this publication are also working on these related projects:

Comparison of « HOME field advantage » importance, for litter decomposition, between aquatic and terrestrial environments in a hyper-diverse TROPical rain forest. "HOME-TROP" View project 


\title{
Fishpond dams affect leaf-litter processing and associated detritivore communities along intermittent low-order streams
}

\author{
Brian Four $^{1,2,3}$ (D) | Marielle Thomas ${ }^{1,3}$ | Evelyne Arce ${ }^{1}$ | Aurélie Cébron ${ }^{4}$ | \\ Michael Danger $^{3,5}$ (D) | Damien Banas ${ }^{1,3}$
}

${ }^{1}$ University of Lorraine, UR AFPA, EA 3998 , USC 340 INRA, Vandoeuvre-lès-Nancy, France

${ }^{2}$ INRA, UAR 1275 DEPT EFPA, Centre de recherche de Nancy, Champenoux, France

${ }^{3}$ LTER 'Zone Atelier Moselle', Vandoeuvrelès-Nancy, France

${ }^{4}$ Université de Lorraine - LIEC, UMR7360 CNRS, Vandœuvre-lès-Nancy, France

${ }^{5}$ Université de Lorraine - LIEC, UMR7360 CNRS, Metz, France

\section{Correspondence}

Four Brian, Unité de Recherche Animal et Fonctionnalités des Produits Animaux (UR AFPA), Equipe Domestication en Aquaculture Continentale (DAC), Université de Lorraine, Faculté des Sciences et Technologies de Nancy, Boulevard des Aiguillettes, BP 70239, Vandoeuvre-lesNancy, France.

Emails: brian.four@inra.fr;

bfour36@gmail.com

Funding information

Agence de l'Eau Rhin-Meuse; Zone Atelier Moselle

\section{Abstract}

1. Intermittent streams are common and widespread freshwater ecosystems globally. While dams greatly affect the ecology of permanent streams, the extent of their effects on intermittent streams remains largely unknown. The physical and chemical alterations induced by dams could have particularly strong impacts on the functioning of intermittent low-order streams, especially due to the limitations they place on colonisation of aquatic biota from downstream permanent waters.

2. Leaf-litter breakdown (LLB) and associated communities (microbes and shredders) were studied to investigate the potential ecological continuum rupture caused by fishpond dams along the longitudinal gradient of intermittent streams. Three to four sites were investigated along three reference (no dam) and three impacted (with a fishpond dam) first-order intermittent low-order streams.

3. LLB increased along the longitudinal gradient in all six streams regardless of the presence of dams (from 1.5 to 8.4 fold over $<1.5 \mathrm{~km}$ distance). This underscores the great variability of low-order stream functioning even at fine scales. Such upstream to downstream gradients need to be taken into account before investigating the effect of any perturbation using LLB as a functional indicator.

4. Fishponds dams tended to increase LLB downstream, and altered the downstream microbial communities (increase in fungal densities) and shredder assemblages (increase in Gammaridae).

5. The effects of fishpond dams on intermittent stream functioning appeared to be most significant when they were associated with changes in hydrology, that is, when fishponds resulted in permanent flows downstream of dams. Our findings suggest that better management of fishpond dams in order to limit hydrological modifications downstream (for instance, by preventing leaks from the dam) could reduce their impact on ecosystem functioning in intermittent streams.

KEYWORDS

ecological processes, fish pond dam, headwaters, litter breakdown, shredders, temporary river 


\section{1 | INTRODUCTION}

Intermittent low-order streams represent a significant proportion of stream networks, and play a crucial role in maintaining ecosystem health of downstream reaches (Acuña et al., 2014; Meyer et al., 2007; Rasmussen et al., 2013). The functioning of forest streams is closely linked to inputs of allochthonous organic matter (OM), including leaf litter and wood (i.e. coarse particulate organic matter; CPOM), from the surrounding catchment. In temperate latitudes, this CPOM is processed in stream by a rich and diverse assemblage of organisms (both microorganisms, primarily fungi and then bacteria, and detritivore invertebrates) during its up- to downstream transfer along the river continuum (Graça \& Canhoto, 2006; Graça et al., 2015; Vannote, Minshall, Cummins, Sedell, \& Cushing, 1980). Microorganisms are responsible for conditioning leaf-litter, which may be a rather refractory food source for detritivores. Such conditioning facilitates the assimilation of allochthonous OM by detritivore invertebrates, and enhances nutrient recycling in streams (Gessner et al., 1999; Hieber \& Gessner, 2002; Pascoal \& Cássio, 2004). Detritivorous invertebrates produce a large quantity of faecal pellets and litter fragment leaves (fine particulate organic matter; FPOM) which may constitute an important food source for other consumers in stream food webs (e.g. Graça \& Canhoto, 2006).

Streams and rivers show natural longitudinal variations in both their communities and functioning due to changes in food source, current velocity and water quality (e.g. Vannote et al., 1980). This is particularly important for the biota of intermittent low-order streams, where conditions are exacerbated by more or less intense drying periods that can strongly affect their communities and functioning (Datry, Corti, Claret, \& Philippe, 2011). Also, the maintenance of a connection between downstream and upstream reaches is essential for ensuring the colonisation of aquatic biological communities from downstream permanent waters after drying events (Acuña et al., 2005; Nadeau \& Rains, 2007). In addition, such low-order streams have been altered by human activities, and many of them have been subject the construction of fishpond dams (i.e. drainable shallow lakes used as extensive fish-production systems). Most of these agrosystems were created, as early as the Middle Ages in Europe (Berka, 1985; Bernard, 2008). Intermittent low-order streams offer adequate hydraulic conditions (low flow) for the sustainability of a dam during much of the year but enable fast pond filling (at times of high flow) after the fishing period. For these reasons, extensive fish-production systems are commonly associated with intermittent low-order streams, especially those located in clay river basins (allowing water retention during dry periods) in lowland plains (Bartout, 2012; personal observation). Oertli and Frossard (2013) estimated that there are more than 300 million such ponds globally, and more than 251,000 fishponds have been recorded in France alone (Bartout \& Touchart, 2013).

Dams built across streams can cause changes in the hydromorphology, water quality, ecological continuum, biodiversity and functioning of downstream lotic ecosystems (e.g. Bunn \& Arthington,
2002; Elosegi \& Sabater, 2013). However, there is little information is available about the impact of fishpond dams on the ecological processes taking place in low-order streams, yet they may have strong impacts on flows in intermittent rivers or streams (Datry, Larned, \& Tockner, 2014). Primarily, the presence of dams on intermittent streams can potentially favour a flow reduction or even a dewatering of streams that consequently could cause the mortality of aquatic organisms and/or a reduction of leaf-litter decomposition (Niu \& Dudgeon, 2011). Secondly, dams can limit the migration and/or recolonisation of some communities (i.e. fish and invertebrates). Finally, some studies showed that the presence of fishponds on streams increases the sedimentation of allochthonous CPOM in fishponds due to low currents and also influences other abiotic parameters downstream (e.g. turbidity and temperature), at least during part of the fish-production cycle (Banas, Masson, Leglize, \& Pihan, 2002; Banas, Masson, Leglize, Usseglio-Polatera, \& Boyd, 2008; Le Louarn \& Bertru, 1991; Touchart \& Bartout, 2010). For example, Touchart and Bartout (2010) showed that these fishponds increase water temperatures by at least by $1^{\circ} \mathrm{C}$ downstream, and a rise in temperature can positively influence microbial activities and accelerate leaf-litter decomposition (Ferreira \& Chauvet, 2011). In addition, fishponds produce autochthonous OM (Nõges, Luup, \& Feldmann, 2010; Vadeboncoeur et al., 2003) in the form of macrophytes, phytoplankton or periphyton, some of which is exported downstream. This autochthonous OM has different chemical properties from the allochthonous OM that normally predominates in low-order streams, with lower $\mathrm{C} / \mathrm{N}$ ratios, higher FPOM/CPOM ratios, and fewer refractory compounds (Banas \& Masson, 2003). Autochthonous OM is therefore more labile and of potential importance in stream food webs. Recent studies also show that increased inputs of labile carbon could accelerate leaf-litter conditioning and have benefits for detritivorous macroinvertebrates (Danger et al., 2013).

Multiple stressors associated with the presence of fishpond dams (e.g. disrupting the river continuum resulting in changes to flow, suspended materials, temperature, $\mathrm{OM}$ and nutrient loads) are likely to have a variety of effects on intermittent low-order streams. Invertebrate communities in such streams are well adapted to flow discontinuity and many of them have developed strategies (terrestrial stage, dormancy, resistance form, migrations to permanent waters, etc.) to survive dry periods (i.e. Arscott, Larned, Scarsbrook, \& Lambert, 2010; Boulton, 2003). However, changes in water flow regime, chemical properties and/or food resources due to the fishponds may affect bacteria, fungi and shredder communities that break down leaflitter in stream. This in turn may affect organic-matter processing and thus stream ecosystem functioning, and perhaps especially so in streams with naturally intermittent flow regimes (Corti \& Datry, 2012; Datry, Corti, \& Philippe, 2012; Datry et al., 2011; Sabater, Timoner, Borrego, \& Acuña, 2016). For evaluating the adverse effects of fishpond dam perturbations on intermittent stream functioning, we chose to evaluate leaf-litter breakdown (LLB) and associated microbial communities. Indeed, such indicators are commonly used as a proxy of ecosystem function in streams (Gessner \& 
Chauvet, 2002; Tank, Rosi-Marshall, Griffiths, Entrekin, \& Stephen, 2010; Woodward et al., 2012), and seems particularly adapted in the case of low order streams.

In this study, we tested the hypothesis that fishpond dams strongly affect the functioning of intermittent low-order streams along their longitudinal gradient. Two contrasting scenarios were considered. On the one hand, LLB rates were expected to increase downstream of dams due to faster litter conditioning attributable to the presence of labile carbon, nutrient releases and temperature elevation downstream. On the other hand, LLB rates were expected to decrease due to community changes (e.g. more collector-feeders and generalist taxa to the detriment of shredders) or with diet changes of shredders (e.g. a preference for rich OM coming from fishponds). To the best of our knowledge, studies performed on the effects of dams on low-order stream functioning are limited to comparisons between one upstream site and one downstream site (e.g. González et al., 2013; Martínez et al., 2013). However, dams could also affect communities in the upper reaches above dams by modifying dispersal and colonisation from downstream permanent waters that is crucial to intermittent low-order streams (Acuña et al., 2005). Therefore, to test our hypothesis, we used a similar study design to that used to test the river continuum concept (e.g. Bott et al., 1985). Three to four sites were investigated along three reference (no dam) and three impacted (with a dam) first-order intermittent low-order streams within a restricted and similar geographical area. We studied the LLB and the associated biological communities (microorganisms and shredders) along a longitudinal gradient.

\section{MATERIALS AND METHODS}

\section{1 | Study sites}

To investigate fishpond effects on stream continuum functioning, six intermittent low-order streams located on the Sarre River basin (Region of Great East, north-eastern France) were studied (Figure 1; Table S1). The stream river beds were relatively homogenous and mainly composed by impermeable clay substratum (Chambre Régionale d'Agriculture de Lorraine - service Agronomie, 1988). These streams are mainly fed by rainwater and show marked seasonal patterns, with dry periods from late spring to autumn, and flow periods from late autumn to spring. Our experimental strategy included a selection of three pairs (denoted A, B, C), each of which consisting of one stream without fishponds (noted Ref) and one stream with a fishpond dam (noted Fp). To establish these three pairs (Ref A and Fp A; Ref B and Fp B; Ref C and Fp C), care was taken to have similar environmental characteristics concerning each lotic system (irrespective of the presence of a fishpond) and its catchment (Tables 1 and S1). For a given pair (Ref and Fp), the catchment areas and their geomorphologic characteristics (calculated using a $25 \mathrm{~m}$ digital elevation model (BD Alti, IGN), ArcGIS Desktop Software and Arc Hydro tool) were therefore similar. The recorded characteristics were also validated by field surveys. The site water quality characteristics are given in Table S1. All the catchments were mainly covered with deciduous forests comprising Carpinus betulus (Betulaceae), Fagus sylvatica and Quercus sp. (Fagaceae). All six studied streams are located within a limited geographical area $\left(38 \mathrm{~km}^{2}\right)$ andin the same hydro-ecological area (homogeneous geology with Triassic sedimentary deposits and climatic conditions; Wasson, Chandesris, Pella, \& Blanc, 2002).

Along the longitudinal gradient of these six streams, we identified three (pair C) or four (pairs A and B) sites (noted S1, S2, S3 and $S 4$, from upstream to downstream, as indicated in Figure 1). Pair $C$ only had three sites because of the short length of the stream downstream S3 in Fp C. Each site covered a 30-m long reach over which leaf bags were deployed. For the streams with fishpond dams (Fp A, $\mathrm{Fp} \mathrm{B}$ and $\mathrm{Fp} \mathrm{C}$ ), the sites S1 and S2 were located upstream of the fishponds, and the sites S3 and S4 were located downstream of the fishponds. A total of 22 sites were therefore selected and, for each pair (A, B or C), these sites were located as far as possible at a similar distance from the source point of the stream and within forested catchments of similar size. Besides, an increased catchment size and/ or leaks from fishpond dams led some downstream sites to have permanent flows (see Table S1). The sites which were continuously flooded during the summer period were named "sites with permanent flow" (the others being referred to as "sites with intermittent flow").

The surface area of the three fishponds was $8,4.7$ and 4.9 ha for Fp A, Fp B and Fp C, respectively. Dating from the Middle Ages, the ponds have been managed for extensive fish polyculture: mainly Cyprinus carpio, Rutilus rutilus, Tinca tinca (Cyprinidae), Esox lucius (Esocidae), Perca fluviatilis and Sander lucioperca (Percidae). Management operations include a 2- to 4-year cycle production involving a three-step process: step 1 consists in filling the ponds with water inputs from small tributaries and precipitations; step 2 is a pseudobalance phase during which fish are stocked and grown in fishponds (for 2-4 years), without any voluntary input (food or chemical products); and finally step 3 is when ponds are emptied to allow fish to be harvested. The present study was conducted during the second step of the management operations.

\section{2 | Leaf-litter breakdown}

Evaluation of LLB and detritivore communities was performed using the leaf-bag method as described by Gessner and Chauvet (2002). Alder (Alnus glutinosa: Betulaceae) leaf litter was chosen to study LLB for two main reasons: (1) this tree species is common in the riparian zones of the selected streams and (2) alder has fast decomposing rate (Petersen \& Cummins, 1974). The latter point was an important consideration for our study which focused on intermittent streams. Due to dry periods during the summer, macroinvertebrate taxa were expected to exhibit annual cycles with both aquatic and terrestrial stages and/or desiccation-resistant stages to survive dry periods buried in streambed sediments (Arscott et al., 2010; Boulton, 2003; Datry et al., 2012). Also, as we had 22 sites at which natural drying can occur at different times, we chose to study LLB and associated communities when hydrology was similar among streams and 
(a)

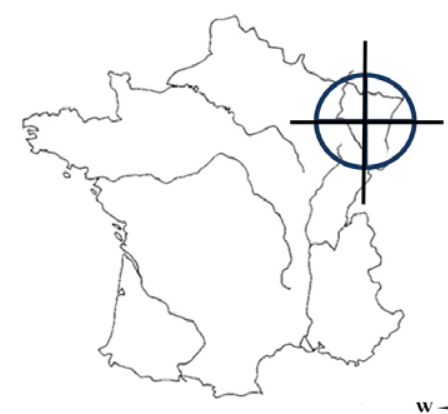

(c)

Ref. A

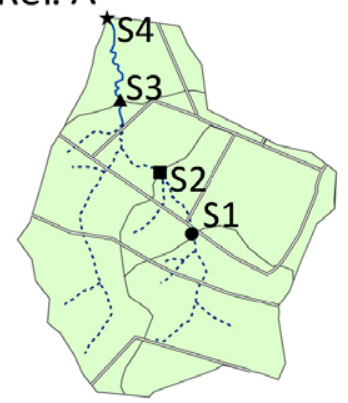

Fp A

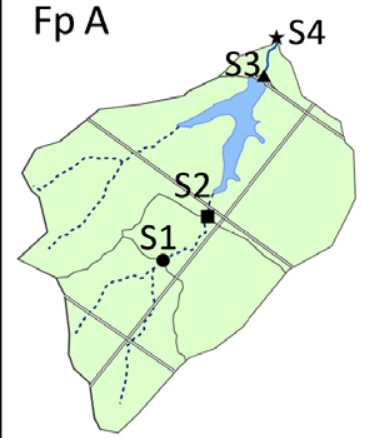

(b)

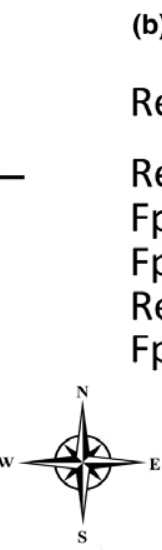

$0 \quad 510 \mathrm{~km}$

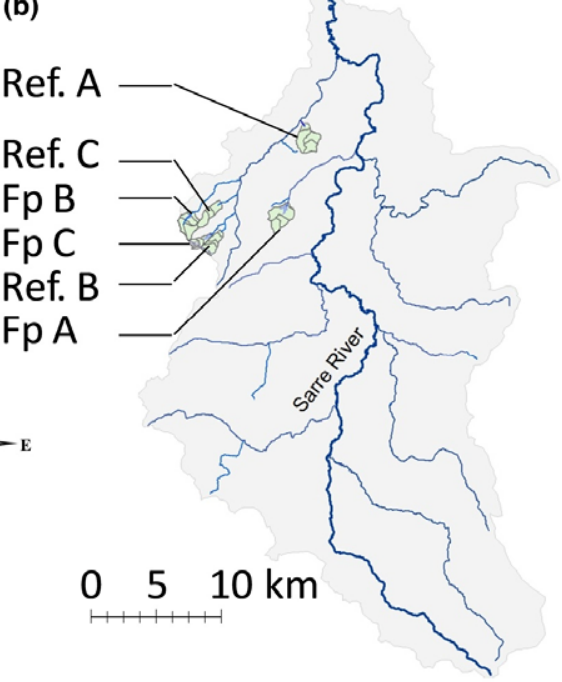

Ref. A

Ref. C

F B

Ref. B

$p$ A

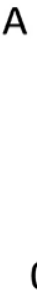

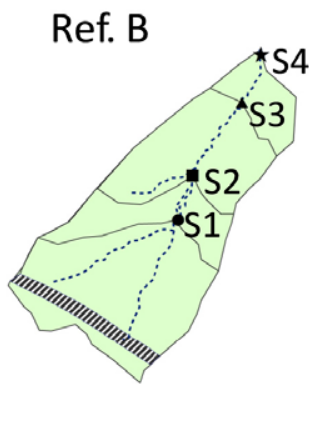

Fp B

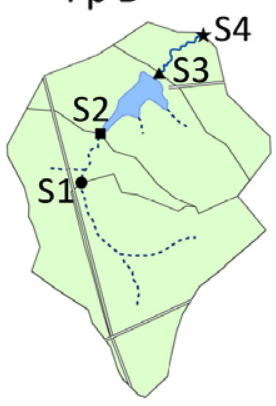

Ref. C

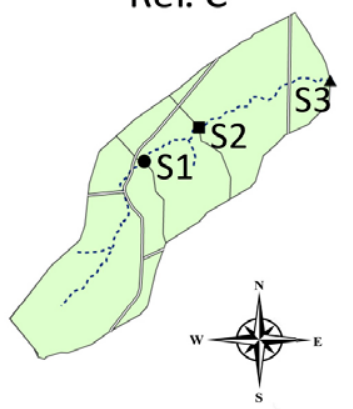

Fp C

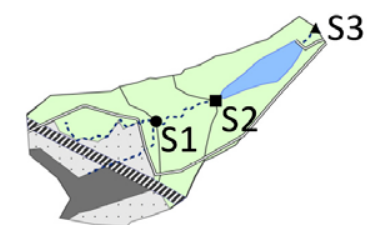

$0 \quad 0.5 \quad 1 \mathrm{~km}$

\section{Legend}

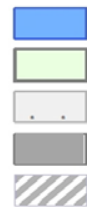

Fishpond

Forest

Pasture

Arable land

Railway

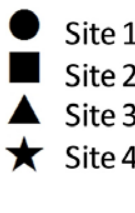

FIGURE 1 Location of the study area. (a) North East France; (b) Sarre river basin and location of the six catchments; (c) land use and site location within catchments. Sites were distributed along a longitudinal gradient from upstream (S1) to downstream (S3-S4) sites (i.e. during the flowing period). Consequently, our study had to be conducted between the end of autumn and the first summer drying. We have carried out our study from January to March, which corresponds to the end of the aquatic life stage for most aquatic insects before emergence in our study area (personal observation).

Alder leaves were collected just after abscission during the autumn 2014 in the Vosges Mountains (North East France) using a net hung between trees. Leaves were air-dried and petiole removed. Three-gram ( $\pm 0.02 \mathrm{~g}$ ) aliquots of this biological material were moistened and enclosed in two types of mesh bags: (1) coarse-mesh bags (10 mm mesh size) allowing shredder colonisation and used to evaluate total LLB rates; (2) fine-mesh bags ( $0.5 \mathrm{~mm}$ mesh size) excluding most shredders and used to evaluate the LLB rates attributed to microbial processing (i.e. fungi and bacteria). Twenty-four bags of 
TABLE 1 Characteristics of the study sites underlying the main fishpond effects on the water parameters

\begin{tabular}{|lll|}
\hline Parameter & $\begin{array}{l}\text { Range between } \\
\text { sites }^{\mathrm{a}}\end{array}$ & $\begin{array}{l}\text { Fishpond } \\
\text { effect }\end{array}$ \\
\hline Distance from source (m) & $940-2,600$ & \\
\hline Catchment area (ha) & $52-252$ & \\
\hline Strahler stream order & $1-2$ & \\
\hline Channel width (m) & $1-3.7$ & - \\
\hline Flow rate (L/s) & $3.5-20.6$ & - \\
\hline Water velocity (cm/s) & $1.4-5.7$ & c. $+1.5^{\circ} \mathrm{C}$ for \\
\hline Temperature ( $\left.{ }^{\circ} \mathrm{C}\right)$ & $2.5-4.7$ & sites from \\
& & the ponds \\
& & - \\
\hline pH & & - \\
\hline Conductivity (S/cm) & $75-732$ & - \\
\hline Turbidity (NTU) & $40-218$ & - \\
\hline $\mathrm{O}_{2}$ (mg/L) & $10.2-12.8$ & - \\
\hline Nitrate (mg/L) & $1.15-5.36$ & - \\
\hline Nitrite (mg/L) & $0.01-0.01$ & - \\
\hline Ammonia (mg/L) & $0.06-0.15$ & - \\
\hline Orthophosphates (mg/L) & $0.01-0.04$ & - \\
\hline
\end{tabular}

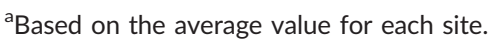

each type were submerged at each site (S1, S2, S3, S4) in the six low-order streams (giving a total of 528 bags per mesh type). Six replicate bags of each type were recovered from the streams at each site after 7, 14, 28 and 42 days, stored individually in zip-lock bags and returned to the laboratory in a cool box. To avoid loss of invertebrates, coarse-mesh bags were removed from the streams using a $0.5 \mathrm{~mm}$ (mesh size) sieve. In the laboratory, leaves were rinsed individually on a $0.5-\mathrm{mm}$ (mesh size) sieve, to remove exogenous material and/or invertebrates, in coarse-mesh bags. All the exogenous material and invertebrates in the coarse-mesh bags were preserved in $70 \%$ ethanol. Leaf samples were oven-dried at $70^{\circ} \mathrm{C}$ for $48 \mathrm{hr}$, weighted to the nearest $0.01 \mathrm{~g}$ and ground. Subsamples of ground leaves from each bag were placed in a muffle furnace for $4 \mathrm{hr}$ at $550^{\circ} \mathrm{C}$ to relate air dry mass to ash-free dry mass (AFDM). We used 10 extra fine-mesh bags that were placed in tap water for $48 \mathrm{hr}$ to evaluate the initial leaching, dry mass and AFDM (i.e. initial leaching accounted for 10.6\%). Remaining leaf mass in the bags exposed in streams was expressed as a ratio between mass of samples and initial leached litter mass expressed in AFDM.

\section{3 | Microorganisms: fungal and bacterial molecular densities}

Evaluation of the fungal and bacterial molecular densities was carried out using leaves enclosed in fine-mesh bags and submerged for 28 and 42 days in the six streams. Only these two dates were selected for analyses because it was a particularly cold year with slow microbial decomposition, and we preferred to focus our analyses on the most advanced decomposition stages. To this end, three bags were randomly taken at each site and a set of five discs were cut out from random leaves in each selected bag (diameter $12 \mathrm{~mm}$ ), avoiding central veins, and frozen at $-18^{\circ} \mathrm{C}$ until processing. The bacterial and fungal density was quantified with the number of $16 \mathrm{~S}$ rRNA and $18 \mathrm{~S}$ rRNA gene copies, respectively, as described by Cébron, Norini, Beguiristain, and Leyval (2008) and Thion, Cébron, Beguiristain, and Leyval (2012). Note that if these approaches can be quite effective to detect changes in the relative density of microbes among different sites, they cannot be used to quantify the absolute microbial biomasses or to compare the number of gene copy between bacteria and fungi (Manerkar et al., 2008).

DNA extraction and real-time qPCR analysis were subsequently performed on these leaf samples. For DNA extraction, subsamples of five leaf discs were carefully fragmented and total DNA was extracted using the PowerSoil DNA Isolation kit (MO BIO Laboratories, Carlsbad, CA). Total DNA concentration in extracts was determined, using a NanoDrop spectrophotometer (ThermoFisher Scientific). Then, a subsample of each extract was diluted with the buffer solution of the PowerSoil kit to $5 \mathrm{ng} / \mathrm{L}$ before amplification. The primers $968 \mathrm{~F}$ and $1401 R$ were used as universal primers for real-time qPCR amplification of bacterial 16SrDNA according to the method described by Cébron et al. (2008). The primers Fung5F and FF390R were used as universal primers for real-time qPCR amplification of fungal 18SrDNA as described by Thion et al. (2012). Bacterial and fungal gene densities were expressed as rRNA gene copies per $\mathrm{cm}^{2}$ of leaf litter.

\subsection{Shredder communities}

Invertebrates sampled at day 14 and day 28 were identified to the lowest practicable taxonomic level (i.e. species, if not genus or family for invertebrates, Tachet, Richoux, Bournaud, \& Usseglio-Polatera, 2010) and counted. Identification and counting were performed with a stereomicroscope (Nikon SMZ-800N). Invertebrates were divided into two groups, shredders and others, according to the feeding guilds described by Tachet et al. (2010). We defined shredders taxa with a frequency of occurrence "shredder feeding habits" of at least 20\% according to Tachet et al. (2010). Moreover, as mainly invertebrate shredders are directly involved in LLB, and also because coarse leaf litter bags are preferentially colonised by this group, we chose to work specifically on shredder assemblages. Biomass was determined by weighing dried individuals $\left(55^{\circ} \mathrm{C}, 48 \mathrm{hr}\right)$ to the nearest $0.1 \mathrm{mg}$. The abundance and richness for the shredder communities were expressed per leaf bags and their biomass was expressed as AFDM of leaf litter remaining in leaf bags.

\section{5 | Data analysis}

LLB rates $\left(k_{f}\right.$ or $k_{c}$, fine- or coarse-mesh bag rates, respectively) of each site were estimated by fitting mass loss data to a negative exponential model as described by the following formula: \% AFDM $_{t}=e^{-k t}$ where \%AFDM ${ }_{t}$ is the percentage of leaf litter AFDM remaining at time $t$ (expressed in days) corrected by the initial AFDM (after leaching), and $k\left(\right.$ day $\left.^{-1}\right)$ is an LLB rate constant. For each 
stream, longitudinal changes in LLB rates were assessed by analysis of covariance (ANCOVA) followed by Tukey's multiple comparison test on the regression lines obtained for each site (S1-S4).

In order, for our data sets, to approximate a normal distribution, density, abundance and biomass data were log transformed. As we had no date effects (i.e. no significant difference between the various sampling dates) on microbial gene density or abundance and biomass of shredders $(p>.05)$, we chose to pool the data across dates from each site.

For each stream, longitudinal dynamics of bacterial and fungal abundance, as well as shredder abundance or biomass considering all sites were assessed using ANOVAs followed by Tukey's HSD tests (Zar, 1996). We calculated the effect size (log ratio of means; Hedges, Gurevitch, \& Curtis, 1999) from each pair (A, B and C) in order to consider a potential fishpond effect on LLB, microbial densities, and shredder abundance and biomass. This analysis allows measuring and comparing the amplitude of the fishpond effect along streams. Effect sizes were calculated for each site of a pair as the ratio between average values (DNA gene copy numbers, shredder abundance and biomass) at the considered site (S1, S2, S3 or S4) in the stream with a fishpond $(\mathrm{Fp})$ and its counterpart (S1, S2, S3 or S4) in the control stream (Ref). For each site (S1-S4) of each stream, a single LLB rate describe the leaf litter decomposition dynamic as well as its associated 95\% confidence interval (using the 6 replicate litter bags sampled per date $\times 4$ dates). By comparing each site of the paired-streams (impacted versus reference), effect size of LLB rates were calculated as the log ratio of the impacted/reference LLB rates and their associated $95 \%$ confidence intervals. Strictly positive log ratios from a given site indicate a significant positive fishpond effect on the considered variable at this site.

To generalize our results, the composition of shredder communities was examined among all sites using non-metric multidimensional scaling (NMDS; Clarke, 1993) followed by PERMANOVA analyses (McArdle \& Anderson, 2001). The similarity matrix was calculated using Bray-Curtis ecological distance on log-transformed densities. Moreover, this analysis aimed to focus on differences among sites (i.e. compositional shift among sites) in order to explain the recorded LLB rate differences. Thus, ordinations were computed using the average density of leaf bags over time (i.e. average density between a given location of a leaf bag at day 14 and its counterpart at day 28) to minimise the temporal colonisation effect. Then, multiple PERMANOVA analyses were performed on the similarity matrix and $95 \%$ confidence interval ellipses were calculated and plotted on the NMDS, to identify the main factors explaining ordination differences among sites. The important categorical factors identified-i.e. streams $(n=6)$, sites (S1, S2, S3, S4), locations (upstream reference, downstream reference, upstream fishpond and downstream fishpond) and annual flow discontinuity (i.e. sites with intermittent flow versus sites with permanent flow) - were presented. To elucidate the main drivers of LLB in these low-order streams, partial least-squares (PLS) regressions (Abdi, 2003) were used to construct a descriptive model predicting LLB across our 22 sites from a panel of selected factors known to influence litter breakdown in low-order streams, including categorical factors (first regression identified with NMDS ordination) and biotic factors (second regression). Categorical factors introduced in the first model were: streams, locations, sites and annual flow discontinuity of the sites. The influence of shredder communities on LLB was assessed by introducing into a second PLS regression model the mean abundance, biomass, relative abundance of total or main groups of shredders (e.g. Ephemeroptera + Plecoptera, Trichoptera, Gammaridae, Asellidae and other taxa), microbial gene densities and microbial LLB rates recorded at each site. The generated variable importance in the projection values (VIP) reflects the quality of a given variable to explain LLB rates with respect to its projection among other variables included in the model. A variable with a VIP score greater than one (in terms of absolute value) can be considered as having great correlation with LLB process. Values negatively correlated with LLB were multiplied by a negative coefficient of minus one on the presented graphic to facilitate interpretation (Figure 9).

All data analyses were performed with $\mathrm{R}$ software ( $\mathrm{R}$ Development Core Team, 2015, using "vegan," "ggplot2," "nlstools," "lattice" and "agricolae" packages) and XLSTAT (Addinsoft). The significance level for all statistical analyses was set at .05.

\section{RESULTS}

\section{1 | Leaf litter breakdown}

Nonlinear regressions provided good estimates of exponential LLB rates: $t$ test for regression slopes: $t>5.7, p<.001$, intercept $(0.96$ 0.98 ) and $t>9.9, p<.001$, intercept (0.98-1.15) for microbial and total litter decay, respectively (see Figure 2). Microbial LLB rates ranged from 0.003 to 0.005 /day and total LLB rates ranged from 0.006 to 0.052 day. Among streams and sites, LLB rates were always higher in coarse- than in fine-mesh leaf bags (Figure 2). Total LLB rates in the upstream sites were variable but within the same range for reference and impacted streams (0.007-0.015 and 0.006-0.023/ day, respectively). Total LLB rates were relatively high (0.041-0.052/ day) in the downstream sites of two impacted streams (A, B) compared to their corresponding sites from the reference streams (0.014-0.034/day)

There were no significant differences in microbial LLB rates between sites along the reference streams (ANCOVA time $\times$ site interaction: $p>$.05). Microbial LLB rates did increase, however, from upstream to downstream in impacted stream $A$ and $B$ (ANCOVA time $\times$ site interaction: $F_{(3,88)} \geq 3.0, R^{2}>.02, p<.04$ ). In impacted stream $C$ no increase was observed, but microbial LLB rates at upstream sites were relatively high compared to all other sites. The downstream site (S3) was in the same range as other sites downstream of fishponds. Moreover, the effect size of the fishpond impact was always positive for both downstream sites (S3 and S4) and with significant effects for four of the five sites (Figure $3 a$ and Table S2). The results were more variable for the upstream sites (i.e. with positive and negative effects, Figure $3 a$ and Table S2). 

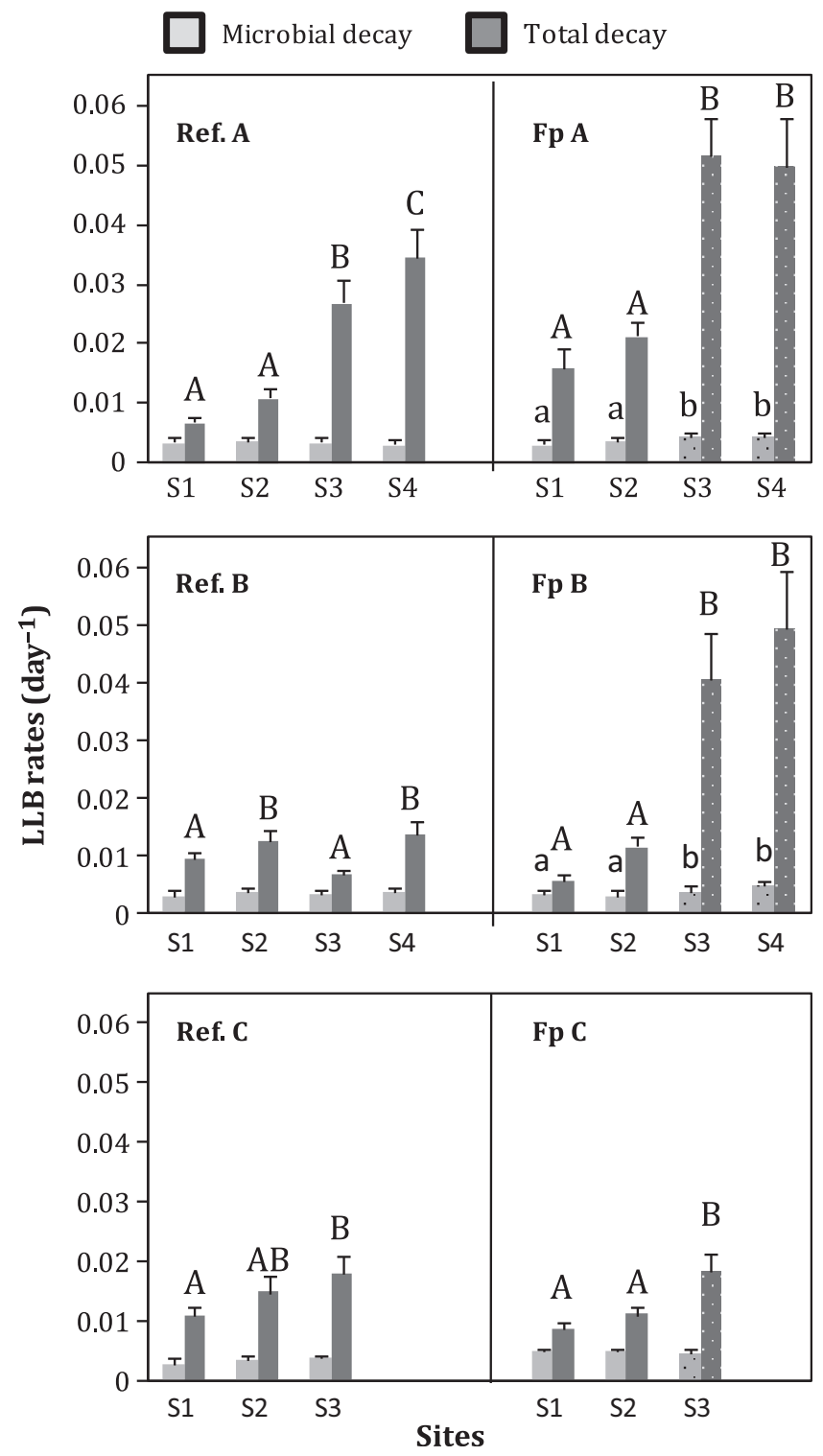

FIGURE 2 Longitudinal gradient and fishpond effects on leaf litter breakdown (LLB). Comparison of microbial (fine-mesh bags) and total (coarse-mesh bags) LLB rates along longitudinal gradient of the three reference (Ref) streams $(A, B, C)$ and the paired impacted ( $F p)$ streams (A, B, C). LLB rates were expressed as day ${ }^{-1}$. Vertical bars indicate $95 \%$ confidence interval and different letters indicate significant differences among sites (S1-S4) within streams (based on ANCOVA)

The total LLB rates differed among sites within each stream (Figure 2, ANCOVA time $\times$ site interaction: $\left(F_{(2,66} \mid 3,88\right) \geq 8.3$, $R^{2}>.05, p<.001$ ), with an overall increase in LLB rates between upstream and downstream sites (except for reference site B). Total breakdown rate ratios between the most upstream (S1) and the most downstream sites (S4 or otherwise S3) of each studied stream were 5.1, 1.5 and 1.6 for reference stream $A, B, C$ and reached 3.4, 8.4 and 2.1 for impacted streams A, B, C, respectively. The LLB rates at downstream sites (S3 and S4) from reference stream $A$, and impacted stream A and B, were relatively high (at least 1.3 times greater than rates recorded at all other sites). The effect size of the (a)

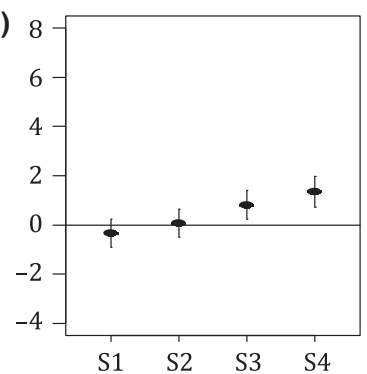



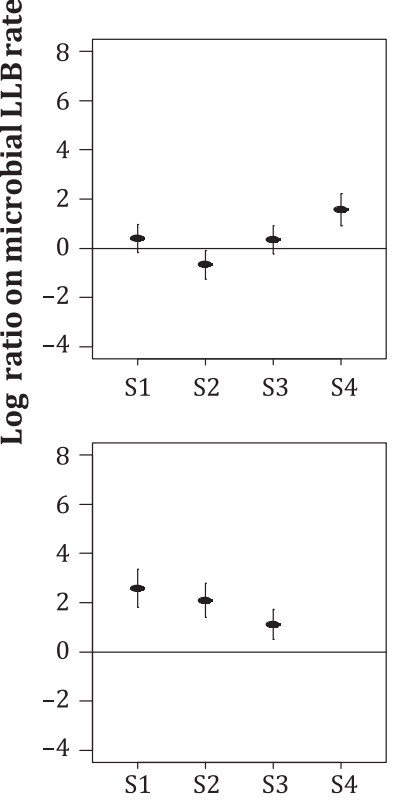

(b)
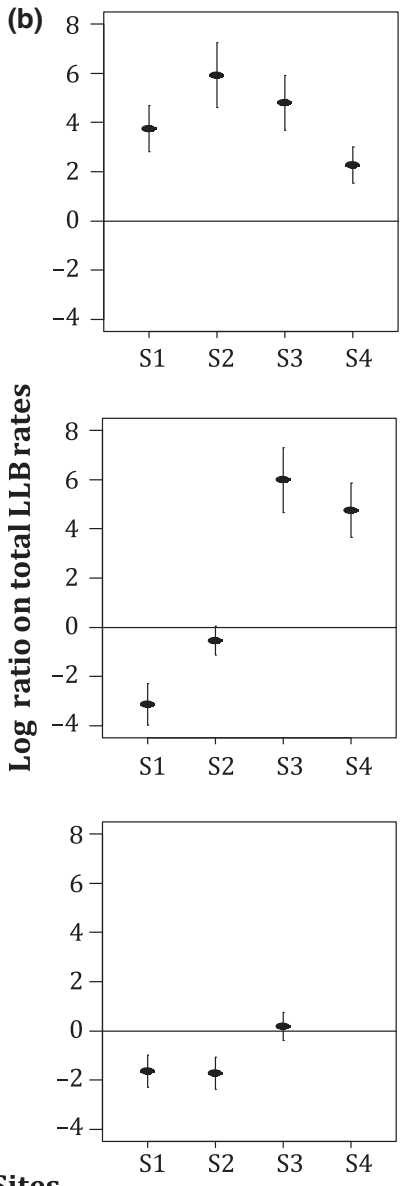

FIGURE 3 Effect size of fishpond (log ratio of response variable, impacted/reference by paired sites) and $95 \%$ confidence intervals for fishpond effects across sites among the pairs ( $A, B$ and $C$ from the top to the bottom, respectively) on microbial leaf litter breakdown (LLB) (a) and total LLB (b). The effect of the fishpond on LLB for individual pair of sites was considered significant when the confidence interval did not overlap zero

fishpond impact on total LLB rates (Figure 3b; Table S2) were highly variable among paired sites at upstream sites (S1 and S2). Besides, at downstream sites, effect sizes were always positive and significant values were recorded for both sites of pair A and pair B (Table S2).

\section{2 | Microbial gene densities}

The microbial gene densities recorded for the three pairs at the different sites are illustrated in Figure 4. Mean fungal gene densities ranged from $5.9 \times 10^{5}$ to $2.9 \times 10^{6}$ and mean bacterial gene densities ranged from $4.5 \times 10^{6}$ to $1.35 \times 10^{7}$ (Figure 4).

Statistical analysis performed on fungal gene density showed significant differences among sites for only one reference stream $\left(F_{(3,20)}=3.2, R^{2}=.33, p=.04\right.$, stream $\left.A\right)$, and for all impacted streams $\left(F_{(2,15} \mid 3,20\right) \geq 3.9, R^{2} \geq .37, p \leq .02$; Figure 4). Reference stream $A$ gene densities showed significant differences between the two downstream sites. However, for the impacted streams, significant differences were always recorded between an upstream site and a downstream site with higher fungal gene densities for the 


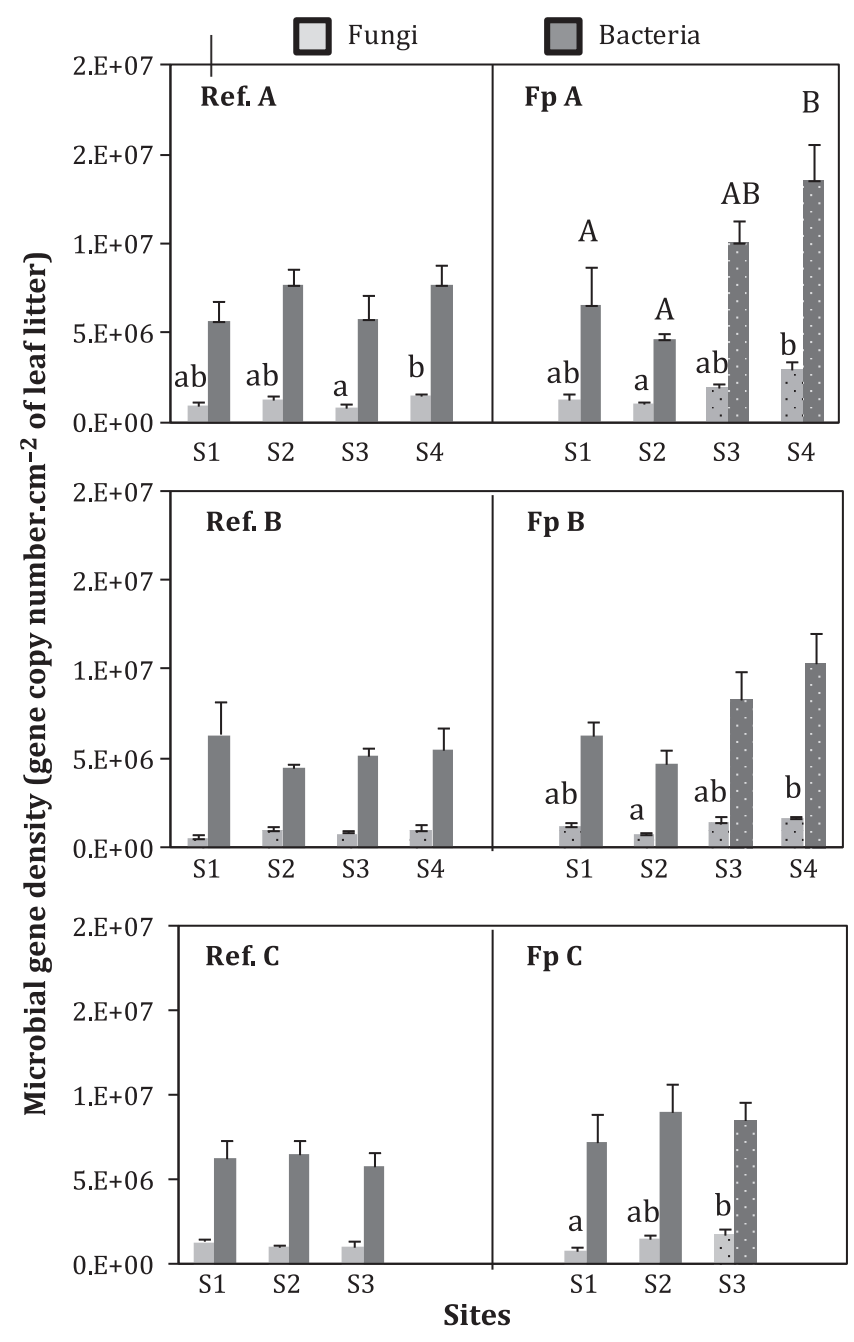

FIGURE 4 Longitudinal gradient and fishpond effects on microbial densities. Comparison of microbial (fungi and bacteria) gene densities ( $t S E, n=6$ ) across the longitudinal gradient of the three reference (Ref) streams (A, B, C) and the three impacted (Fp) streams (A, B, C). Different letters indicate significant differences among sites (S1-S4) within streams (based on ANOVA). Note that relative abundance of fungi and bacteria are not comparable

downstream sites. Accordingly, effect sizes performed on fungal gene densities for each site from pairs A, B and C (Figure 5a, Table S3) were always positive for both downstream sites (S3 and S4) but with significant effects only for pair A. For upstream sites, effect sizes were more variable between streams and did not underline any fishpond effect.

Statistical analysis performed on bacterial gene densities showed significant differences among sites only for one fishpond stream (stream A: $F_{(3,20)}=4.7, R^{2}=.37, p=.01 ; S 4$ significantly higher than both upstream sites S1 and S2) (Figure 4). At upstream sites (S1 and S2), effect sizes of the fishpond impact were variable with only one significant value at S2 for pair A (Figure 5b). However, at both downstream sites (S3 and S4) mean estimate values of effect sizes of the fishpond impact were always positive but only one significant fishpond effect was recorded (for pair B-S4; Table S3).
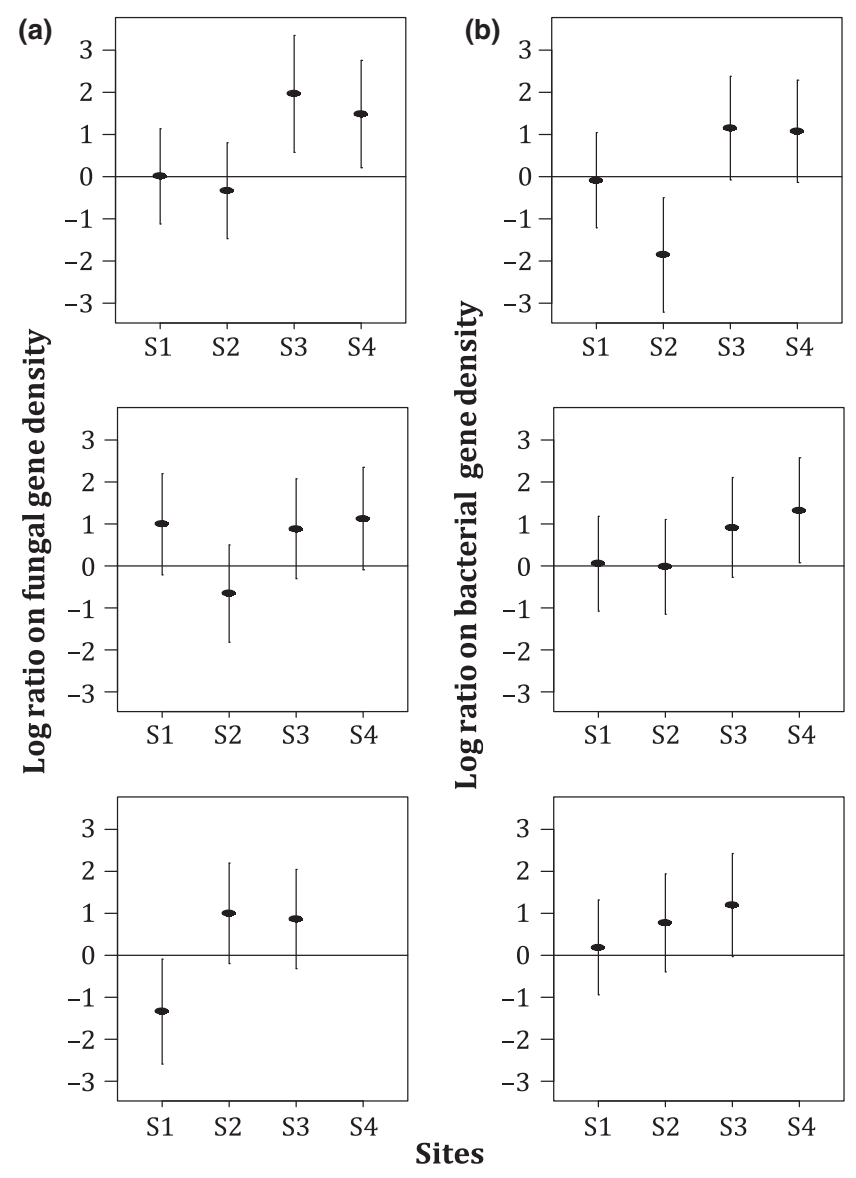

FIGURE 5 Effect size of fishpond (log ratio of response variable, impacted/reference by paired sites) and $95 \%$ confidence intervals for fishpond effects across sites among the pairs (A, B and C from the top to the bottom, respectively) on (a) fungal and (b) bacterial gene densities. The effect of the fishpond on microbial densities for individual pair of sites was considered significant when the confidence interval did not overlap zero

\section{3 | Shredders}

Overall, in the 264 coarse-mesh bags (22 sites $\times 6$ replicates $\times 2$ dates), 11,084 individuals were counted and identified, $67.1 \%$ of which were classified as shredders. Among the 21 different shredder taxa identified, more than $37.3 \%$ were Gammarus pulex (Gammaridae), while $29.7 \%, 11.8 \%, 6.7 \%$ and $4.6 \%$ were Nemoura (Nemouridae), Potamopyrgus (Tateidae), Asellus aquaticus (Asellidae) and Glyphotaelius pellucidus (Limnephilidae), respectively. All other taxa taken together accounted for $<10 \%$ of total shredder individuals. They belonged mainly to two orders, Plecoptera and Trichoptera. Among all leaf bags, shredder abundance varied from 0 to 557 individuals per $\mathrm{g}$ leaf litter AFDM. Shredder biomass varied from 0.4 to $1638 \mathrm{mg}$ of dried individuals per $\mathrm{g}$ leaf litter AFDM.

The abundance and biomass of shredders recorded at each site are given in Figure 6. Shredder abundance only showed significant differences among the sites for impacted streams $\left(F_{(2,33} \mid 3,44\right) \geq$ 5.3, $R^{2} \geq .26, p<.001$ for all fishpond streams; Figure 6), with an overall significant increase from upstream to downstream sites. Effect sizes of the fishpond impact were mainly negative at both 
upstream sites (S1 and S2, except for pair A-S2) with significant values at both upstream sites for pairs B and C (Figure 7a, Table S4). In contrast, at downstream sites, effect sizes of the fishpond impact were more variable. However, significant positive values were observed at both downstream sites for pairs $A$ and $B$.

As Figure 6 shows, shredder biomass was significantly different among sites for one reference stream $\left(F_{(3,44)}=13.4, R^{2}=.48\right.$, $p<.001$; stream $A)$ as well as for all fishpond streams $\left(F_{(2,33}\right.$ । 3, 44) $\geq$ 16.6, $\left.R^{2} \geq .50, p<.001\right)$. At upstream sites, effect sizes related to shredder biomass appeared to be variable and were only significant at upstream sites for pair A (Figure 7b, Table S4). In contrast, for downstream sites, effect sizes were always significantly positive indicating much higher biomass of shredders in sites downstream of fishponds.

The two-dimensional NMDS ordination of shredder communities at the sites and the overlap of confidence ellipses among the identified categorical factors are given in Figure 8. Shredder assemblages appeared to be significantly different between streams

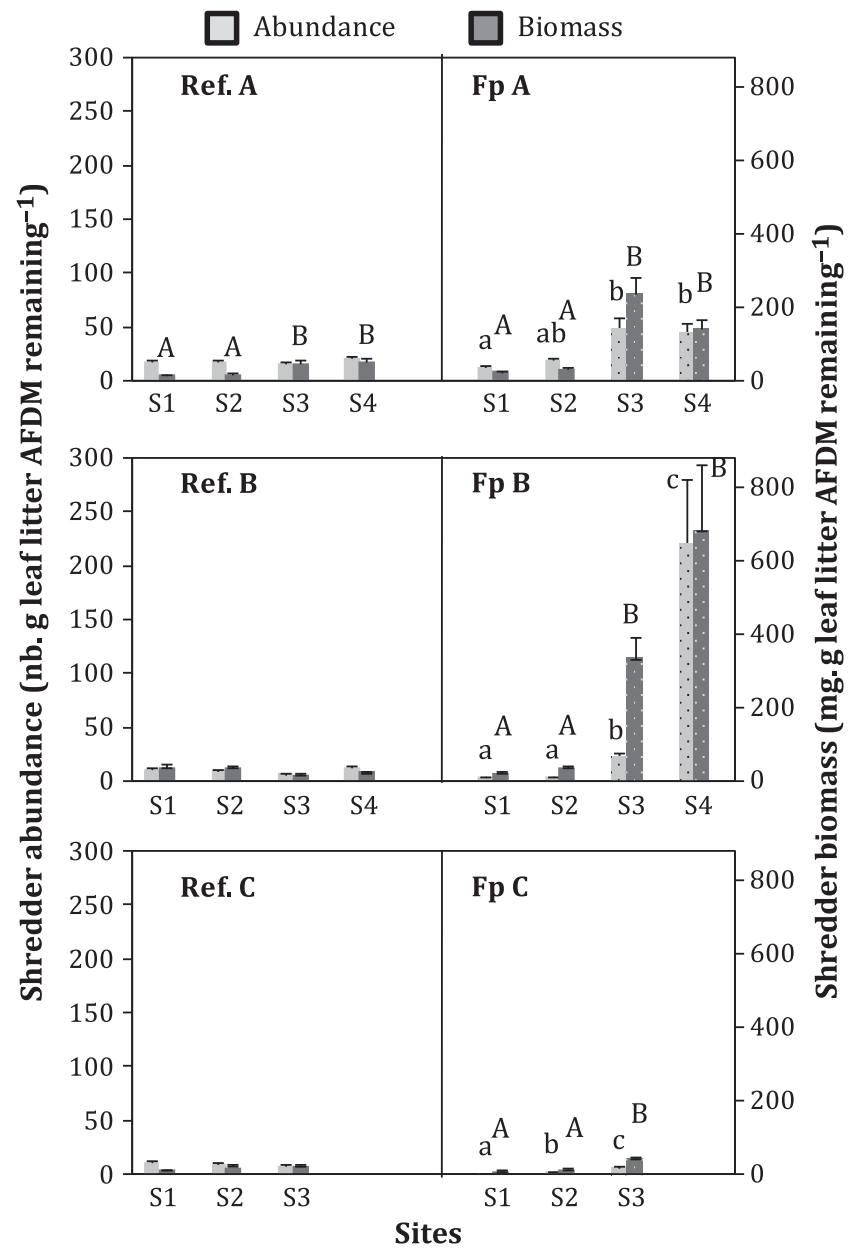

FIGURE 6 Longitudinal gradient and fishpond effects on shredders. Comparison of shredder abundance and biomass $( \pm S E$, $n=12$; expressed as number or grams per gram of remaining leaf litter AFDM) across the longitudinal gradient of the three reference (Ref) streams (A, B, C) and the three impacted (Fp) streams (A, B, C). Different letters indicate significant differences among sites (S1-S4) within streams (based on ANOVA)
(PERMANOVA results: $p<.001$; Figure 8b, Table S5). Also, shredder assemblages of reference stream $A$ appeared to be different from all other streams due to the presence of specific taxa (e.g. Potamopyrgus, Figure 8a). Furthermore, the confidence ellipses obtained from the three fishpond streams were always larger than those obtained from the three reference streams thus indicating a greater change in community composition along the longitudinal gradient of the fishpond streams. Invertebrate communities changed slightly along the longitudinal gradient ( $p=.01$; Figure 8c; Table S5). When classifying our sites according to the studied locations (Figure 8d; Table S5), we recorded significant differences ( $p<.001$; Table S5). Sites downstream of fishponds were different from the sites upstream of fishponds and also different from all reference sites. The difference was mainly due to the dominance of two taxa, i.e. G. pulex and Proasellus (Asellidae), at sites downstream of fishponds whereas all other sites were dominated by Plecoptera and Trichoptera (Figure 8a). Finally, when considering the classification based on annual water flow discontinuity of the sites (Figure 8e; Table S5), sites with intermittent
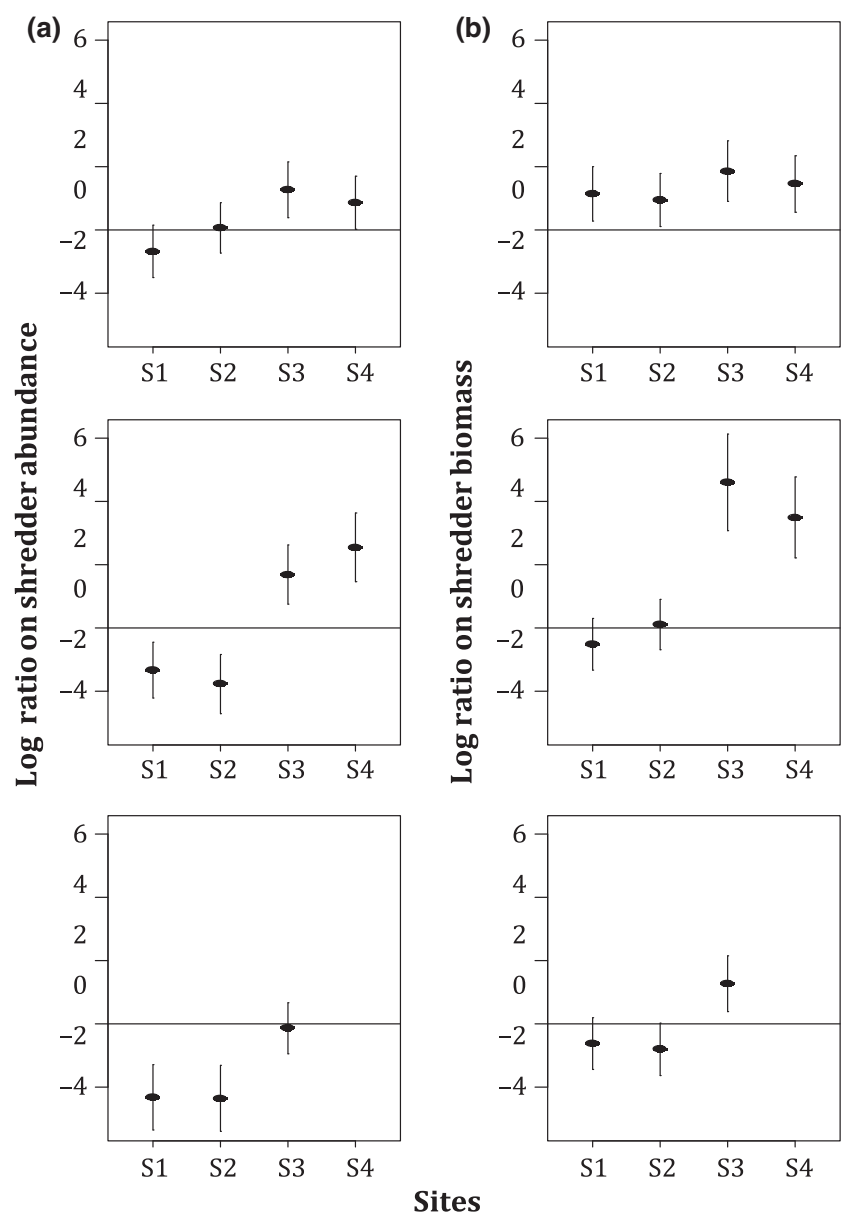

FIGURE 7 Effect size of fishpond (log ratio of response variable, impacted/reference by paired sites) and $95 \%$ confidence intervals for fishpond effects across sites among the pairs ( $A, B$ and $C$ from the top to the bottom, respectively) on (a) shredder abundance and (b) shredder biomass. The effect of the fishpond on shredders for individual pair of sites was considered significant when the confidence interval did not overlap zero 

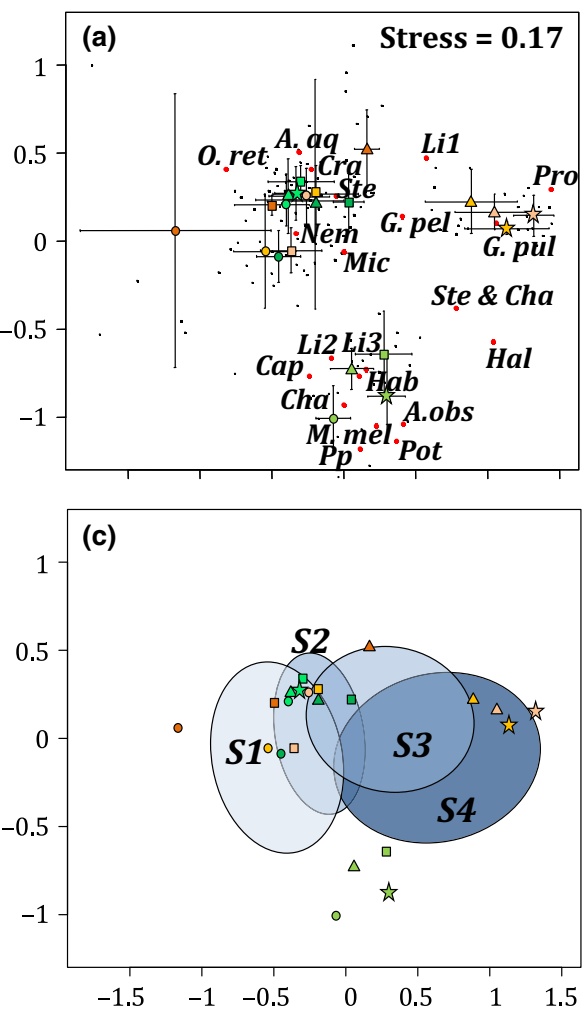

(b)
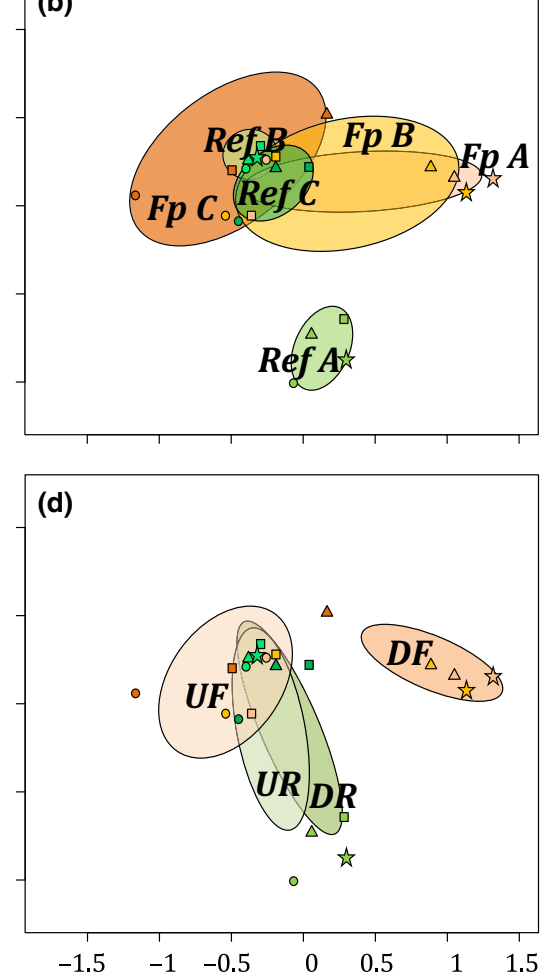

S1 S2 S3 S4

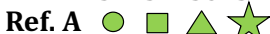

Ref. B $\bigcirc \square \triangle \hat{\psi}$

Ref. C $\square \triangle$

FpA $\bigcirc \square \triangle \widehat{W}$

Fp B $\bigcirc \square \Delta \hat{\psi}$

Fp C $\square \triangle$

FIGURE 8 Ordination of detritivore taxonomic composition by non-metric multi-dimensional scaling. (a) Shredder taxa and average coordinates ( $\pm S D, n=6$ ) for the 22 sites. Average coordinates for the 22 sites and $95 \%$ ellipse confidence for streams (b), sites (c), longitudinal location (d) with upstream reference (UR), downstream reference (DR), upstream fishpond (UF) and downstream fishpond (DF) and (e) with intermittent (I) and permanent (P) flows. The acronyms S1, S2, S3, S4 indicate sites from top to bottom of the catchment; Ref A, Ref B and Ref $\mathrm{C}$ indicate reference streams and $\mathrm{Fp} \mathrm{A}, \mathrm{Fp} \mathrm{B}$ and $\mathrm{Fp} \mathrm{C}$ indicate streams impacted by fishpond. The taxa (panel a) were abbreviated as follows A. aq.: Asellus aquaticus; Li1: Limnephilus; Cra.: Crangonyx; Mic.: Micropterna; O. ret: Oligostomis reticulata; Ste.: Stenophylax; Nem.: Nemoura; G. pel.: Glyphotaelius pellucidus; Pro.: Proasellus; G. pul.: Gammarus pulex; Ste.\& Cha.: Stenophylacini and Chaetopterygini; Hab.: Habrophlebia; Li2: Limnephilidae; Li3: Limnephilini; Hal.: Halesus; Cha. Chaetopteryx; Cap.: Capnia; Pp: Potamopyrgus; A. obs.: Annitella obscurata; M. mel.: Melampophylax melampus; Pot.: Potamophylax

flow showed significant differences $(p<.001)$ in shredder community composition compared to sites with permanent flow.

\subsection{Categorical and biological factors associated with leaf litter breakdown}

The relative importance of the different predictive variables are presented in Figure 9 using PLS regressions with separate VIP scores for categorical (Figure 9a) and biological factors (Figure 9b).

Considering all variables included in PLS regressions, both models explained well the variation in total LLB (86.4\% and $78.9 \%)$ for PLS on categorical factors and on biological factors, respectively. The three significant categorical factors predicting LLB among the 22 sites were water flow discontinuity (intermittent flow versus permanent flow) of streams (VIP: 1.91; Figure 9a); sites downstream of the fishponds (VIP: 1.67); and site S4 (VIP: 1.11). Regarding biological factors (Figure $9 \mathrm{~b}$ ), total biomass of shredders was the best predictor of LLB rates (VIP: 1.63). This factor was highly correlated $(d f=21, r>.50, p<.05)$ with the other nine significant factors (i.e. Gammaridae metrics, microbial densities, total abundance of shredders, Trichoptera biomass as positive correlated factors and Ephemeroptera plus Plecoptera [EP] proportion or biomass as negative correlated factors). Moreover, among these factors, the high values obtained from Gammaridae metrics indicated that total LLB rates were highly associated with density of Gammaridae. In addition, the moderate negative VIP value (-1.35) recorded for EP proportion indicated that EP were good predictors of LLB and that high proportions are associated with low LLB. Similarly, microbial densities could be relatively good predictors (VIP: 1.23 and 1.22 for fungal and bacterial gene densities, respectively).

\section{DISCUSSION}

\section{1 | Is the presence of a fishpond important for ecosystem functioning in intermittent low-order streams?}

Fishponds affected both intermittent stream ecosystem functioning (LLB rates) and community structure (invertebrates, bacteria and fungi). Total LLB rates of alder leaves measured in the reference streams (i.e. without fishpond) were similar to those reported by Datry et al. (2011) for intermittent and permanent streams. An increase in the total LLB rates along the longitudinal gradient was recorded for almost all the 

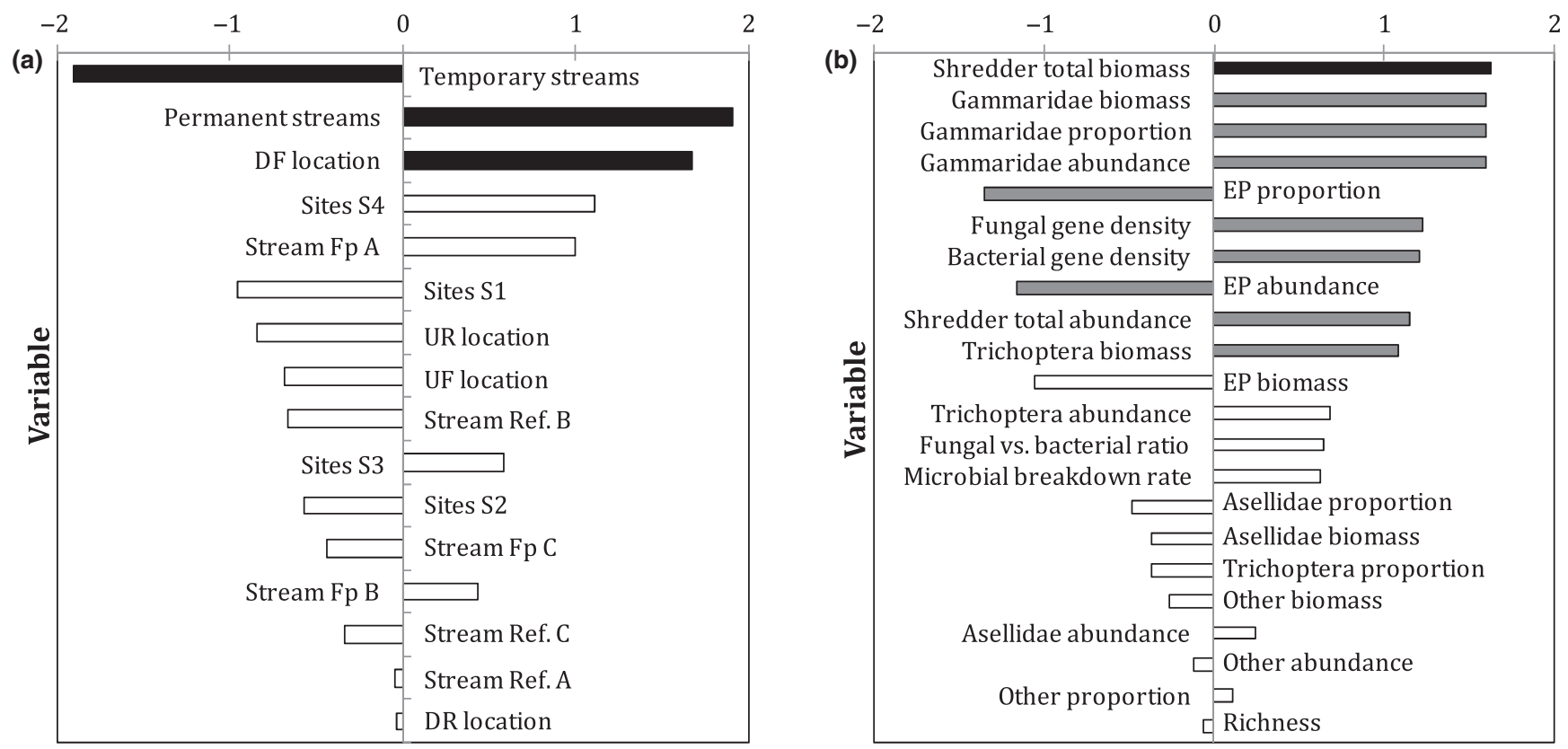

FIGURE 9 Effects of predictors on total leaf litter breakdown (LLB) rates ( $n=22$ sites) from the PLS regressions analysis: (a) categorical factors and (b) biological factors. Highest relative values indicate the best predicting factors, with variable importance in the projection higher than 1 considered significant. Positive values are positively related, and negative ones are negatively related with LLB. Left panel shows the importance of identified categorical factors (a) and right panel shows the importance of biological factors (b) associated with LLB. Black bars represent the most important categorical factors (a) and biological factor (b). Grey bars show variables significantly correlated with the most important variable (df 21; $r>.50 ; p<.05$, Pearson rank test). UF, upstream fishpond; DF, downstream fishpond; UR, upstream reference; DR, downstream reference; EP, ephemeroptera and plecoptera

studied streams (except for one reference stream). The presence of fishponds generally stimulated total LLB at the downstream sites, although other studies have shown variable effects of dams on LLB (Casas, Zamora-Munoz, Archila, \& Alba-Tercedor, 2000; Four et al., 2017; Martínez et al., 2013; Menéndez, Descals, Riera, \& Moya, 2012) depending on the water chemistry, the type of dam, or the land use at sites up- and downstream of the dams. Nevertheless, we observed high variability in the extent of stimulation of total LLB downstream of fishponds and, in stream $\mathrm{C}$, the increase remained within the range of changes attributable to the longitudinal gradient (i.e. up- to downstream) in reference streams.

In contrast to the total LLB, microbial LLB rates did not increase along the longitudinal gradient of reference streams and were rather low, and less than those reported from other studies of microbial decomposition of alder (e.g. Lecerf \& Chauvet, 2008; Lecerf \& Richardson, 2010). However, our results in reference streams were consistent with those obtained by Datry et al. (2011) who reported limited microbial activities from late winter to early spring because of low water temperatures, similar to those recorded during our field experiments (Tables 1 and S1), and thus we suspect a limiting effect of temperature (Rajashekhar \& Kaveriappa, 2000; Sridhar \& Bärlocher, 1993). Nonetheless, the significant VIP obtained for bacterial and fungal gene densities (Figure 9b) suggest that microbes could contribute to driving of LLB in low-order streams through their role in conditioning leaves. The presence of fishpond dams can lead to an increase in water temperature downstream (Four et al., 2017; Menéndez et al., 2012), and such an increase was observed in our study (c. $1.5^{\circ} \mathrm{C}$ higher than at other sites; Table S1). As previously highlighted (Ferreira \& Chauvet, 2011; Menéndez et al., 2012; Sridhar \& Bärlocher, 1993), warmer conditions can favour microbial assemblages by increasing both their activities and densities. This may explain the higher microbial LLB rates (in stream A and B) and microbial gene densities (in stream $C$ ) downstream of the fishponds (Figure 4). As the effect of fishponds was even stronger for fungal gene densities, fungi may be more sensitive than bacteria to abiotic conditions. Other studies have already shown this fungal sensitivity in particular to variations in dissolved oxygen, with fungal activity being reduced by $60 \%$ when oxygen falls to $76 \%$ of oxygen saturation (Harrop, Marks, \& Watwood, 2009; Medeiros, Pascoal, \& Graça, 2009). Reductions in oxygen availability could occur within leaf-litter packs due to clogging or burial by fine sediments, such effects being even more pronounced when water flow is modified by dams (Colas et al., 2016). As we did not observed any increased in clogging of litter downstream of dams in our study, it is plausible that the increased water flow and, consequently, litter oxygenation resulting from dams upstream, favoured fungi in downstream reaches. We must stress, however, that the methodology used did not measure the activity of microorganisms but rather their relative densities, and better understanding of the role of different microbes in LLB could be achieved using an approach based on measuring the enzymatic activities of fungi and bacteria (e.g. Schneider et al., 2010). Indeed, microbial LLB was higher only at the sites downstream of fishponds and it was mainly due to a slight increase in fungal densities (Figure 4). A positive effect of aquatic hyphomycete richness or biomass 
on LLB favouring the abundance of shredders has already been shown in several studies (e.g. Chung \& Suberkropp, 2009; Lecerf, Dobson, Dang, \& Chauvet, 2005). Greater conditioning of litter could first increase the degradation rate of leaf refractory polymers, which in turn facilitates the assimilation of allochthonous resources by benthic shredders (e.g. Graça et al., 2015; Nelson, 2011).

In the present study, we did not record any shift in shredder densities (colonising coarse-mesh litter bags) between the most upstream and the most downstream sites in the reference streams (except for biomass between up- and downstream sites in reference stream A), and an absence of any longitudinal gradient in shredder abundance at the scale of our study (c. $1.5 \mathrm{~km}$ ). The presence of fishponds clearly affected macroinvertebrate community in both directions (i.e. up- and downstream of ponds), with shifts in community composition along the longitudinal gradient (Figure 8a, d). Shredders abundance and biomass were generally low upstream and consistently increased downstream from the fishponds, with gammarids and asellids predominating. The lower shredder abundances recorded upstream of the fishponds could probably result from a disruption of the downstream to upstream colonisation by aquatic macroinvertebrate communities occurring in intermittent streams due to the presence of the dam (Acuña et al., 2005). Small-dam-related changes in shredder assemblages have been reported in the literature (e.g. Martínez et al., 2013; Mendoza-Lera et al., 2012) but reflect an overall decrease in the density of shredders. The increase in shredder densities that we recorded was mainly due to gammarids, and a similar finding by Menéndez et al. (2012),, where the presence of a dam was also associated with higher microbial conditioning and LLB rates downstream, suggests that gammarids may be favoured in such environmentals. We suspect that where intermittent streams became permanent downstream of fishpond dams, G. pulex was favoured by high food quality but also and probably mainly by permanent flows, which would also account for the high LLB rates we observed under these conditions. In fact, at the downstream site in impacted stream $C$ that had intermittent flows, shredder assemblages were intermediate between reference and impacted streams and the dominance of G. pulex was not observed. Microbial gene densities and water temperatures at this site were in the same range as those of other sites downstream of the fishpond dams, suggesting that changes in flow were an important driver of fishpond impacts on stream functioning.

Our results show that fishponds located on intermittent loworder streams seemed to affect LLB rates and litter-associated communities (microbes and shredders) downstream of dams, and led to an overall increase in litter decomposition due to an increase in detritivore densities and activities. However, considering the extent of the variability observed between the three fishpond streams, we urge caution in making broad generalisations form our findings.

\subsection{Longitudinal gradient and flow continuity as important drivers of litter breakdown in small intermittent low-order streams impacted by fishponds}

Total LLB rates increased with the distance from the source in all streams (Figure 2 and Table S1). Unfortunately, most studies dealing with the effects of dams on ecosystem functioning in streams only compare upstream sites with those downstream of dams (e.g. Casas et al., 2000; Martínez et al., 2013; Menéndez et al., 2012). However, as our results from reference streams show, LLB varied significantly along a short longitudinal gradient in low-order streams. This was particularly noticeable when stream hydrology varied substantially along this gradient, as in reference stream A which was intermittent in the upstream reaches and permanent further downstream. This finding validates our experimental design and emphasises the need to take into account the variability of functional processes along the longitudinal gradient of streams before considering any potential effects of dams.

Continuity of flow was the most important driver of LLB, followed by the effect of fishponds (Figure 9a). Since the highest LLB rates were recorded at the sites with permanent flows during the summer (Figure 2; Table S1), ecosystem functioning is influenced more strongly by drying patterns (see Datry et al., 2011) than by fishpond presence itself. This is in agreement with other studies reporting greater breakdown rates in permanent rivers than in intermittent rivers (Boulton, 1991; Datry et al., 2011; Pinna \& Basset, 2004). Furthermore, total LLB rates at downstream intermittent sites were always higher than those at the most upstream sites. This was despite the fact that in all of these downstream sites current velocity, which is known to be an important driver of LLB (Boulton et al., 2008; Graça et al., 2015; Niu \& Dudgeon, 2011), was not systematically greater than at upstream sites (Table S1). However, since the low-order streams studied here were characterised by generally low current velocity, it may not have had a strong influence on LLB. It was notable that the first dry events at downstream sites occurred at later date than at upstream sites, suggesting that the duration of dry episodes and the distance to permanently flowing water (from 100 to $700 \mathrm{~m}$ ) would both have been shorter. Datry et al. (2011) and Datry (2012) recorded a similar pattern and named it the "drying memory of rivers." This concept suggests that LLB rates and densities of litter-associated invertebrate densities decrease with increasing duration of drying events. Our study confirmed that the longitudinal gradient in total LLB in our intermittent streams was in accordance with the major changes in natural flow observed among sites during the year (Table S1). However, during the period when surface flow was maintained, shredder abundance and composition structure of shredder communities did not change markedly along this longitudinal gradient (Figures 6 and 8c). This finding suggests a limited effect of the "drying memory" in our study streams. Indeed, it has already been reported that invertebrate assemblages in intermittent rivers recover quickly after flow has resumed (Acuña et al., 2005; Boulton \& Lake, 1992; Datry, 2012).

The second PLS regression performed on the biological metrics confirmed the functional dichotomy observed between sites with permanent flow and sites with intermittent flow regardless of fishpond presence (Figure 9b). The best predictors of LLB in our streams were linked to the total shredder biomass and the dominance of Gammaridae. Both metrics are known to positively 
influence LLB (e.g. Dangles, Gessner, Guerold, \& Chauvet, 2004; Dangles \& Malmqvist, 2004; Piscart, Genoel, Doledec, Chauvet, \& Marmonier, 2009). Moreover, several studies have shown that numerous taxa, and especially shredders, are sensitive or intolerant to drying events, and are less abundant in intermittent streams compared to permanent streams (Arscott et al., 2010; Datry et al., 2012; Williams, 2006). This is not surprising as the gammarid species found in our streams (mainly G. pulex) are essentially aquatic taxa with multiannual life cycles (Tachet et al., 2010). Even if they can survive in the hyporheic zone of streams (Datry et al., 2012; Vander Vorste et al., 2016), they must be strongly affected by the drying events, especially when the hyporheic zone is desiccated (Vander Vorste et al., 2016) and/or non-functional as in the streams studied here. Thus, abundance of Gammaridae may be a good predictor of LLB along intermittent streams (Mas-Martí, Romaní, \& Muñoz, 2015; Vander Vorste et al., 2016). However, the dominance of Gammaridae was only observed downstream of fishponds in reaches with permanent flow. They were less abundant at downstream reference sites with permanent flow suggesting that flow discontinuity was not the only parameter that influenced gammarid abundance. Although we did not observe changes in nutrients downstream of fishponds (Table S1), we rule out the possibility that fishes and plankton reared in the fishpond produce labile OM that could favour microbes (Rodríguez-Lozano, Rieradevall, \& Prat, 2016) or Gammaridae and thus enhance LLB downstream of the fishpond (Mclntyre et al., 2008; Rodríguez-Lozano et al., 2016). We also cannot exclude a modification of fish communities in streams, due to the escape of cultured fish, which could potentially modify any top-down effect on LLB (RodríguezLozano et al., 2016).

Overall, our findings show that fishpond effects on intermittent stream functioning are significant and amplified (with marked changes in shredder communities) when they are associated with hydrological changes resulting from water leaks from dams. Consequently, in the particular case of fishpond dams constructed on intermittent streams, better management of fishpond dams ensuring that the intermittent nature of the downstream flow maintained during summer when streams are normally dry. This would sustain the aquatic-terrestrial habitat mosaics naturally existing in these streams (see Larned, Datry, Arscott, \& Tockner, 2010), could reduce the impact of fishponds on low-order stream functioning.

\section{ACKNOWLEDGMENTS}

The authors gratefully acknowledge the financial support for this project by the "Agence de l'Eau Rhin-Meuse" and the "Zone Atelier Moselle." We sincerely thank P. Hartmeyer, A. luretig, P. Chaud, R. Chevalier, B. Le Carrer and Y. Namokel for their field and laboratory work, as well as fish farmers, the "Domaine de Lindre," the "Office National des Forêts" and E. De Turkheim for providing us with access permits for sampling. The authors are grateful to the anonymous reviewers, the Associated Editor, B. Demars, and to the Editor-
in-Chief, D. Dudgeon, for their suggestions that have significantly improved the quality of the manuscript.

\section{REFERENCES}

Abdi, H. (2003). PLS-regression; Multivariate analysis. In M. Lewis-Beck, A. Bryman, \& T. Futing (Eds.), Encyclopedia for research methods for the social sciences. Thousand Oaks (CA): Sage. http://www.utdallas.ed u/ herve/Abdi-PLS-pretty.pdf.

Acuña, V., Datry, T., Marshall, J., Barceló, D., Dahm, C. N., Ginebreda, A., ... Palmer, M. A. (2014). Why should we care about temporary waterways? Science, 343, 1080-1081.

Acuña, V., Muñoz, I., Giorgi, A., Omella, M., Sabater, F., \& Sabater, S. (2005). Drought and postdrought recovery cycles in an intermittent Mediterranean stream: Structural and functional aspects. Journal of the North American Benthological Society, 24, 919-933.

Arscott, D. B., Larned, S., Scarsbrook, M. R., \& Lambert, P. (2010). Aquatic invertebrate community structure along an intermittence gradient: Selwyn river, New Zealand. Journal of the North American Benthological Society, 29, 530-545.

Banas, D., \& Masson, G. (2003). New plate sediment traps for lentic systems. Archiv für Hydrobiologie, 158, 283-288.

Banas, D., Masson, G., Leglize, L., \& Pihan, J. C. (2002). Discharge of sediments, nitrogen $(\mathrm{N})$ and phosphorus $(\mathrm{P})$ during the emptying of extensive fishponds: Effect of rain-fall and management practices. Hydrobiologia, 472, 29-38.

Banas, D., Masson, G., Leglize, L., Usseglio-Polatera, P., \& Boyd, C. E. (2008). Assessment of sediment concentration and nutrients loads in effluents drained from extensively-managed fishponds in France. Environmental Pollution, 152, 679-685.

Bartout, P. (2012). Les étangs du Limousin: des zones humides face au développement durable. Editions les Monédières. Brive-la-Gaillarde. 250 pp.

Bartout, P., \& Touchart, L. (2013). L'inventaire des plans d'eau français : Outil d'une meilleure gestion des eaux de surface. Annales de géographie, 122, 266-289.

Berka, R. (1985). A brief insight into the history of Bohemian carp pond management. In R. Billard \& J. Marcel (Eds.), Aquaculture of cyprinids (pp. 35-45). Paris: INRA.

Bernard, C. (2008). L'étang, l'homme et l'oiseau: Incidences des modes de gestion des étangs piscicoles sur les ceintures de végétation et l'avifaune nicheuse en Sologne, Brenne, Bresse, Territoire de Belfort et Champagne humide. PhD thesis, École normale supérieure de Lyon, Lyon, France.

Bott, T. L., Brock, J. T., Dunn, C. S., Naiman, R. J., Ovink, R. W., \& Petersen, R. C. (1985). Benthic community metabolism in four temperate stream systems: An inter-biome comparison and evaluation of the river continuum concept. Hydrobiologia, 123, 3-45.

Boulton, A. (1991). Eucalypt leaf decomposition in an intermittent stream in south-eastern Australia. Hydrobiologia, 211, 123-136.

Boulton, A. J. (2003). Parallels and contrasts in the effects of drought on stream macroinvertebrate assemblages. Freshwater Biology, 48, 11731185.

Boulton, A. J., Boyero, L., Covich, A. P., Dobson, M., Lake, S., \& Pearson, R. (2008). Are tropical streams ecologically different from temperate streams? In D. Dudgeon (Ed.), Tropical stream ecology (pp. 257-284). Amsterdam: Academic Press.

Boulton, A., \& Lake, P. S. (1992). The ecology of two intermittent streams in Victoria, Australia. III. Temporal changes in faunal composition. Freshwater Biology, 27, 123-138.

Bunn, S. E., \& Arthington, A. H. (2002). Basic principles and ecological consequences of altered flow regimes for aquatic biodiversity. Environmental Management, 30, 492-507.

Casas, J. J., Zamora-Munoz, C., Archila, F., \& Alba-Tercedor, J. (2000). The effect of a headwater dam on the use of leaf bags by invertebrate communities. Regulated Rivers Research \& Management, 16, 577-591. 
Cébron, A., Norini, M.-P., Beguiristain, T., \& Leyval, C. (2008). Real-time $\mathrm{PCR}$ quantification of $\mathrm{PAH}$-ring hydroxylating dioxygenase (PAH$\mathrm{RHD} \alpha$ ) genes from Gram positive and Gram negative bacteria in soil and sediment samples. Journal of Microbiological Methods, 73, 148159.

Chambre Régionale d'Agriculture de Lorraine - service Agronomie (1988). Atlas des sols de Lorraine. Retrieved from http://www.cra-lorraine.fr/ index.php?page $=057$ \&article $=14$

Chung, N., \& Suberkropp, K. (2009). Contribution of fungal biomass to the growth of the shredder, Pycnopsyche gentilis (Trichoptera: Limnephilidae). Freshwater Biology, 54, 2212-2224.

Clarke, K. R. (1993). Non-parametric multivariate analyses of changes in community structure. Austral Ecology, 18, 117-143.

Colas, F., Baudoin, J. M., Chauvet, E., Clivot, H., Danger, M., Guérold, F., \& Devin, S. (2016). Dam-associated multiple-stressor impacts on fungal biomass and richness reveal the initial signs of ecosystem functioning impairment. Ecological Indicators, 60, 1077-1090.

Corti, R., \& Datry, T. (2012). Invertebrates and sestonic matter in an advancing wetted front travelling down a dry river bed (Albarine, France). Freshwater Science, 31, 1187-1201.

Danger, M., Cornut, J., Chauvet, E., Chavez, P., Elger, A., \& Lecerf, A. (2013). Benthic algae stimulate leaf litter decomposition in detritusbased headwater streams: A case of aquatic priming effect? Ecology, 94, 1604-1613.

Dangles, O., Gessner, M. O., Guerold, F., \& Chauvet, E. (2004). Impacts of stream acidification on litter breakdown: Implications for assessing ecosystem functioning. Journal of Applied Ecology, 41, 365-378.

Dangles, O., \& Malmqvist, B. (2004). Species richness-decomposition relationships depend on species dominance: Biodiversity and dominance in ecosystems. Ecology Letters, 7, 395-402.

Datry, T. (2012). Benthic and hyporheic invertebrate assemblages along a flow intermittence gradient: Effects of duration of dry events: River drying and temporary river invertebrates. Freshwater Biology, 57, 563-574.

Datry, T., Corti, R., Claret, C., \& Philippe, M. (2011). Flow intermittence controls leaf litter breakdown in a French temporary alluvial river: The "drying memory". Aquatic Sciences, 73, 471-483.

Datry, T., Corti, R., \& Philippe, M. (2012). Spatial and temporal aquaticterrestrial transitions in the temporary Albarine River, France: Responses of invertebrates to experimental rewetting. Freshwater Biology, 57, 716-727.

Datry, T., Larned, S. T., \& Tockner, K. (2014). Intermittent rivers: A challenge for freshwater ecology. BioScience, 64, 229-235.

Elosegi, A., \& Sabater, S. (2013). Effects of hydromorphological impacts on river ecosystem functioning: A review and suggestions for assessing ecological impacts. Hydrobiologia, 712, 129-143.

Ferreira, V., \& Chauvet, E. (2011). Future increase in temperature more than decrease in litter quality can affect microbial litter decomposition in streams. Oecologia, 167, 279-291.

Four, B., Arce, E., Danger, M., Gaillard, J., Thomas, M., \& Banas, D. (2017). Catchment land use-dependent effects of barrage fishponds on the functioning of headwater streams. Environmental Science and Pollution Research, 24, 5452-5468.

Gessner, M. O., \& Chauvet, E. (2002). A case for using litter breakdown to assess functional stream integrity. Ecological Applications, 12, 498510.

Gessner, M. O., Chauvet, E., \& Dobson, M. (1999). A perspective on leaf litter breakdown in streams. Oikos, 85, 377-384.

González, J. M., Mollá, S., Roblas, N., Descals, E., Moya, Ó., \& Casado, C. (2013). Small dams decrease leaf litter breakdown rates in Mediterranean mountain streams. Hydrobiologia, 712, 117-128.

Graça, M. A. S., \& Canhoto, C. (2006). Leaf litter processing in low order streams. Limnetica, 25, 001-010.

Graça, M. A. S., Ferreira, V., Canhoto, C., Encalada, A. C., GuerreroBolaño, F., Wantzen, K. M., et al. (2015). A conceptual model of litter breakdown in low order streams. International Review of Hydrobiology, 100, 1-12.

Harrop, B. L., Marks, J. C., \& Watwood, M. E. (2009). Early bacterial and fungal colonization of leaf litter in Fossil Creek, Arizona. Journal of North American Benthological Society, 28, 383-396.

Hedges, L. V., Gurevitch, J., \& Curtis, P. S. (1999). The meta-analysis of response ratios in experimental ecology. Ecology, 80, 1150-1156.

Hieber, M., \& Gessner, M. O. (2002). Contribution of stream detrivores, fungi, and bacteria to leaf breakdown based on biomass estimates. Ecology, 83, 1026-1038.

Larned, S. T., Datry, T., Arscott, D. B., \& Tockner, K. (2010). Emerging concepts in temporary-river ecology. Freshwater Biology, 55, 717738.

Le Louarn, H., \& Bertru, G. (1991). Influence des élevages extensifs en étang sur les rivières. Revue des sciences de l'eau, 4, 315-327.

Lecerf, A., \& Chauvet, E. (2008). Intraspecific variability in leaf traits strongly affects alder leaf decomposition in a stream. Basic and Applied Ecology, 9, 598-605.

Lecerf, A., Dobson, M., Dang, C. K., \& Chauvet, E. (2005). Riparian plant species loss alters trophic dynamics in detritus-based stream ecosystems. Oecologia, 146, 432-442.

Lecerf, A., \& Richardson, J. S. (2010). Litter decomposition can detect effects of high and moderate levels of forest disturbance on stream condition. Forest Ecology and Management, 259, 2433-2443.

Manerkar, M. A., Seena, S., \& Bärlocher, F. (2008). Q-RT-PCR for assessing archaea, bacteria, and fungi during leaf decomposition in a stream. Microbial Ecology, 56, 467-473.

Martínez, A., Larrañaga, A., Basaguren, A., Pérez, J., Mendoza-Lera, C., \& Pozo, J. (2013). Stream regulation by small dams affects benthic macroinvertebrate communities: From structural changes to functional implications. Hydrobiologia, 711, 31-42.

Mas-Martí, E., Romaní, A. M., \& Muñoz, I. (2015). Consequences of warming and resource quality on the stoichiometry and nutrient cycling of a stream shredder. PLoS ONE, 10, e0118520. https://doi. org/10.1371/journal.pone.0118520

McArdle, B. H., \& Anderson, M. J. (2001). Fitting multivariate models to community data: A comment on distance-based redundancy analysis. Ecology, 82, 290-297.

McIntyre, P. B., Flecker, A. S., Vanni, M. J., et al. (2008). Fish distributions and nutrient cycling in streams: Can fish create biogeochemical hotspots? Ecology, 89, 2335-2346.

Medeiros, A. O., Pascoal, C., \& Graça, M. A. S. (2009). Diversity and activity of aquatic fungi under low oxygen conditions. Freshwater Biology, 54, 142-149.

Mendoza-Lera, C., Larrañaga, A., Pérez, J., Descals, E., Martínez, A., Moya, O., et al. (2012). Headwater reservoirs weaken terrestrial-aquatic linkage by slowing leaf-litter processing in downstream regulated reaches. River Research and Applications, 28, 13-22.

Menéndez, M., Descals, E., Riera, T., \& Moya, O. (2012). Effect of small reservoirs on leaf litter decomposition in Mediterranean headwater streams. Hydrobiologia, 691, 135-146.

Meyer, J. L., Strayer, D. L., Wallace, J. B., Eggert, S. L., Helfman, G. S., \& Leonard, N. E. (2007). The contribution of headwater streams to biodiversity in river networks 1 : The contribution of headwater streams to biodiversity in river networks. Journal of the American Water Resources Association, 43, 86-103.

Nadeau, T. L., \& Rains, M. C. (2007). Hydrological connectivity between headwater streams and downstream waters: How science can inform policy. Journal of the American Water Resources Association, 43, 118 133.

Nelson, D. (2011). Gammarus-microbial interactions: A review. International Journal of Zoology, 2011, 6.

Niu, S. Q., \& Dudgeon, D. (2011). The influence of flow and season upon leaf-litter breakdown in monsoonal Hong Kong streams. Hydobiologia, 663, 205-215. 
Nõges, T., Luup, H., \& Feldmann, T. (2010). Primary production of aquatic macrophytes and their epiphytes in two shallow lakes (Peipsi and Võrtsjärv) in Estonia. Aquatic Ecology, 44, 83-92.

Oertli, B., \& Frossard, P.-A. (2013). Mares et étangs - Ecologie, gestion, aménagement et valorisation. Lausanne, Switzerland: Presses Polytechniques et universitaires romandes.

Pascoal, C., \& Cássio, F. (2004). Contribution of fungi and bacteria to leaf litter decomposition in a polluted river. Applied and Environmental Microbiology, 70, 5266-5273.

Petersen, R. C., \& Cummins, K. W. (1974). Leaf processing in a woodland stream. Freshwater Biology, 4, 343-368.

Pinna, M., \& Basset, A. (2004). Summer drought disturbance on plant detritus decomposition processes in three river Tirso (Sardinia, Italy) sub-basins. Hydrobiologia, 522, 311-319.

Piscart, C., Genoel, R., Doledec, S., Chauvet, E., \& Marmonier, P. (2009). Effects of intense agricultural practices on heterotrophic processes in streams. Environmental Pollution, 157, 1011-1018.

R Development Core Team (2015). The R Project for Statistical Computing. https://www.r-project.org/

Rajashekhar, M., \& Kaveriappa, K. M. (2000). Effects of temperature and light on sporulation of aquatic hyphomycetes. Hydrobiologia, 441, 149-153.

Rasmussen, J. J., McKnight, U. S., Loinaz, M. C., Thomsen, N. I., Olsson, M. E., Bjerg, P. L., et al. (2013). A catchment scale evaluation of multiple stressor effects in headwater streams. Science of The Total Environment, 442, 420-431.

Rodríguez-Lozano, P., Rieradevall, M., \& Prat, N. (2016). Top predator absence enhances leaf breakdown in an intermittent stream. Science of the Total Environment, 572, 1123-1131.

Sabater, S., Timoner, X., Borrego, C., \& Acuña, V. (2016). Stream biofilm responses to flow intermittency: From cells to ecosystems. Frontiers in Environmental Science, 4, article 14.

Schneider, T., Gerrits, B., Gassmann, R., Schmid, E., Gessner, M. O., et al. (2010). Proteome analysis of fungal and bacterial involvement in leaf litter decomposition. Proteomics, 10, 1819-1830.

Sridhar, K. R., \& Bärlocher, F. (1993). Effect of temperature on growth and survival of five aquatic hyphomycetes. Sydowia, 45, 377-387.

Tachet, H., Richoux, F., Bournaud, M., \& Usseglio-Polatera, P. (2010). Invertébrés d'eau douce: Systématique, biologie, écologie. Paris: CNRS.

Tank, J. L., Rosi-Marshall, E. J., Griffiths, N. A., Entrekin, S. A., \& Stephen, M. L. (2010). A review of allochthonous organic matter dynamics and metabolism in streams. Journal of the North American Benthological Society, 29, 118-146.

Thion, C., Cébron, A., Beguiristain, T., \& Leyval, C. (2012). Long-term in situ dynamics of the fungal communities in a multi-contaminated soil are mainly driven by plants. FEMS Microbiology Ecology, 82, 169181.

Touchart, L., \& Bartout, P. (2010). The influence of monk equipped ponds on the quality of basin head streams, the example of water temperature in Limousin and Berry (France). Lakes Reservoirs and Ponds Romanian Journal of Limnology, 4, 81-108.

Vadeboncoeur, Y., Jeppesen, E., Vander Zanden, M. J., Schierup, H.-H., Christoffersen, K., \& Lodge, D. M. (2003). From greenland to green lakes: Cultural eutrophication and the loss of benthic pathways in lakes. Limnology and Oceanography, 48, 1408-1418.

Vander Vorste, R., Mermillod-Blondin, F., Hervant, F., Mons, R., Forcellini, M., \& Datry, T. (2016). Increased depth to the water table during river drying decreases the resilience of Gammarus pulex and alters ecosystem function. Ecohydrology, 9, 1177-1186.

Vannote, R. L., Minshall, G. W., Cummins, K. W., Sedell, J. R., \& Cushing, C. E. (1980). The river continuum concept. Canadian Journal of Fisheries and Aquatic Sciences, 37, 130-137.

Wasson, J. C., Chandesris, A., Pella, H., \& Blanc, L. (2002). Typology and reference conditions for surface waterbodies in France: The hydroecoregion approach. In M. Ruoppa \& K. Karttunene (Eds.), Typology and classification of lakes and rivers (pp. 37-41). Helsinki, Finland: Tema Nord 566.

Williams, D. D. (2006). The biology of temporary waters. Oxford: Oxford University Press.

Woodward, G., Gessner, M. O., Giller, P. S., Gulis, V., Hladyz, S., et al. (2012). Continental-scale effects of nutrient pollution on stream ecosystem functioning. Science Magazine, 336, 1438-1440.

Zar, J. H. (1996). Biostatistical analysis. Eryelwood Cliffs, NJ: PrenticeHall. 663 pp.

\section{SUPPORTING INFORMATION}

Additional Supporting Information may be found online in the supporting information tab for this article.

How to cite this article: Four B, Thomas M, Arce E, Cébron A, Danger M, Banas D. Fishpond dams affect leaf-litter processing and associated detritivore communities along intermittent low-order streams. Freshwater Biol. 2017;00:1-15. https://doi.org/10.1111/fwb.12984 